Prepared in cooperation with the Washington County Water Conservancy District

\title{
Numerical Simulation of Groundwater Movement and Managed Aquifer Recharge from Sand Hollow Reservoir, Hurricane Bench area, Washington County, Utah
}

Scientific Investigations Report $2012 \div 5236$

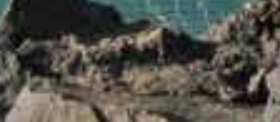

A.S. Department of the niterio U.S. Geologfloal Sunvey 
Cover photograph: View of the North Dam of Sand Hollow Reservoir and Sand Hollow Basin. Photo by Tom M. Marston, January 2012. 


\section{Numerical Simulation of Groundwater Movement and Managed Aquifer Recharge from Sand Hollow Reservoir, Hurricane Bench area, Washington County, Utah}

By Thomas M. Marston and Victor M. Heilweil

Prepared in cooperation with the Washington County Water Conservancy District

Scientific Investigations Report 2012-5236 


\title{
U.S. Department of the Interior \\ KEN SALAZAR, Secretary \\ U.S. Geological Survey \\ Marcia K. McNutt, Director
}

\author{
U.S. Geological Survey, Reston, Virginia: 2012
}

For more information on the USGS - the Federal source for science about the Earth, its natural and living resources, natural hazards, and the environment, visit http://Www.usgs.gov or call 1-888-ASK-USGS.

For an overview of USGS information products, including maps, imagery, and publications, visit $h t t p: / / w w w . u s g s . g o v / p u b p r o d$.

To order this and other USGS information products, visit http://store.usgs.gov.

Any use of trade, product, or firm names is for descriptive purposes only and does not imply endorsement by the U.S. Government.

Although this report is in the public domain, permission must be secured from the individual copyright owners to reproduce any copyrighted materials contained within this report.

Suggested citation:

Marston, T.M., and Heilweil, V.M., 2012, Numerical simulation of groundwater movement and managed aquifer recharge from Sand Hollow Reservoir, Hurricane Bench area, Washington County, Utah: U.S. Geological Survey

Scientific Investigations Report 2012-5236, 34 p. 


\section{Contents}

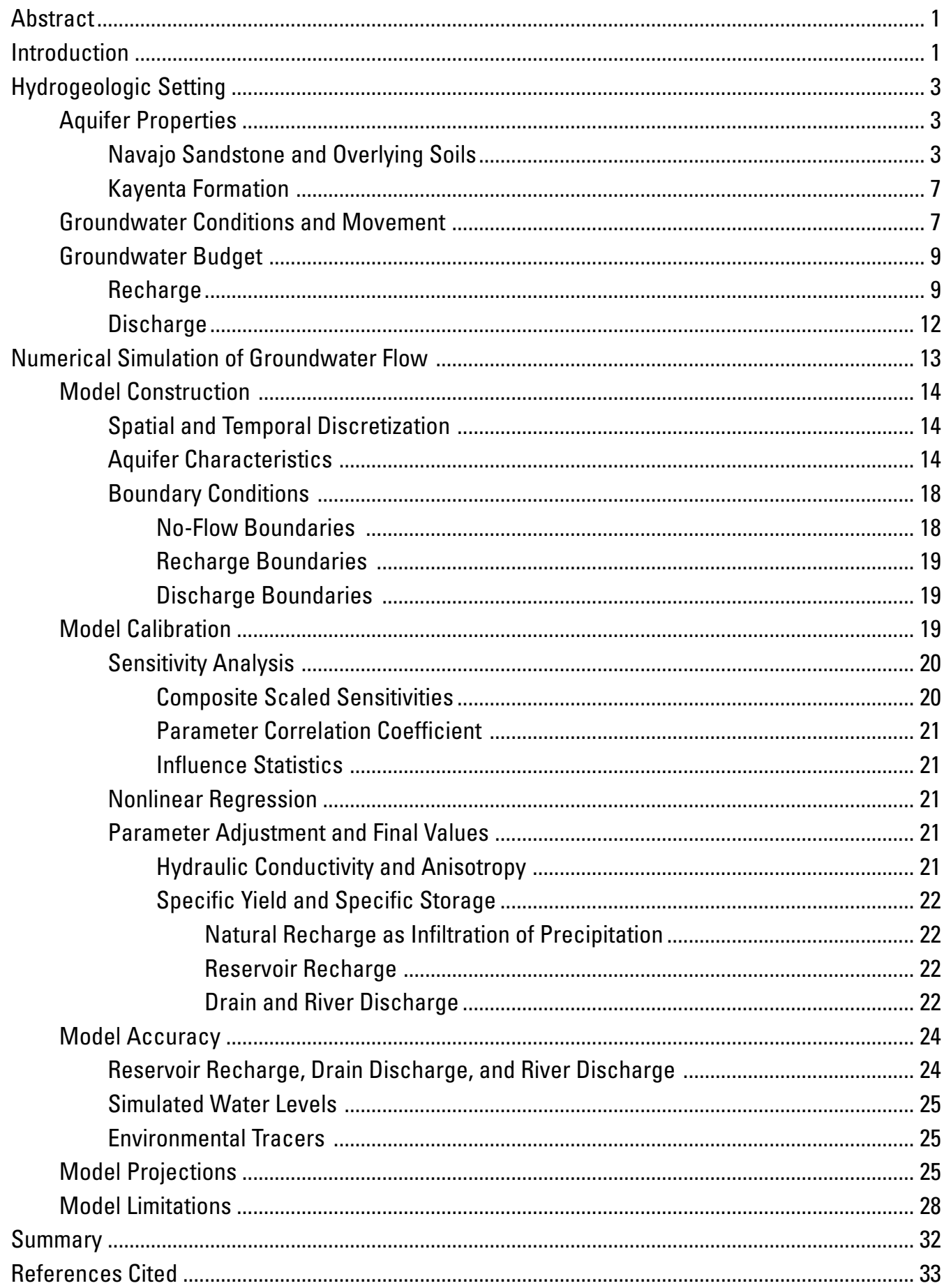

\section{Figures}

1. Map showing the Hurricane Bench study area, Washington County, Utah ........................ 2

2. Location map of bedrock fractures and faults in the Hurricane Bench area, Utah.............. 4 
3. Map showing location of monitoring wells, production wells, irrigation wells, and drains in the Hurricane Bench area, Utah.

4. Map showing potentiometric surface of the Navajo aquifer prior to completion of Sand Hollow Reservoir, Hurricane Bench area, Utah 8

5. Graph showing observed water levels from 1971 to 2009 at the (C-42-14)12dbb-1 monitoring well in the Hurricane Bench area, Utah 9

6. Map showing potentiometric surface of the Navajo aquifer near Sand Hollow Reservoir, Hurricane Bench area, Utah, August 2009 10

7. Graph showing estimated and simulated groundwater recharge from Sand Hollow Reservoir, Hurricane Bench area, Utah

8. Graph showing estimated withdrawals from wells in the Hurricane Bench area, Utah, 1975-2009

9. Graph showing measured pumping and simulated discharge from the West Dam, West Dam Spring, and North Dam drains, Hurricane Bench area, Utah 13

10. Map showing model grid of the groundwater system and zones of low, medium, and high recharge from precipitation in the Hurricane Bench area, Utah

11. Generalized cross sections along column 19 and row 51 of the groundwater-flow model for the Hurricane Bench area, Utah

12. Map showing hydraulic-conductivity zones of the Navajo Sandstone in the Hurricane Bench area, Utah

13. Graph showing composite scaled sensitivities for model parameters in the groundwater-flow model for the Hurricane Bench area, Utah.

14. Map showing bed conductance zones of the Reservoir Package representing vertical hydraulic conductivity beneath Sand Hollow Reservoir, Hurricane Bench area, Utah

15. Graph showing temporally varying reservoir-bed hydraulic conductivity parameters that define a portion of the total recharge simulated in flat low-lying areas in Sand Hollow

Reservoir, Hurricane Bench area, Utah

16. Graphs showing observed and simulated water levels at monitoring wells in Sand Hollow, Hurricane Bench area, Utah.

17. Map showing difference between observed and simulated water levels measured in December 2009 for monitoring wells around Sand Hollow Reservoir, Hurricane Bench area, Utah.

18. Map showing simulated groundwater-flow paths from Sand Hollow Reservoir, Hurricane Bench area, Utah.

19. Map showing projected travel time of managed aquifer recharge moving through the Navajo Sandstone in Sand Hollow, Hurricane Bench area, Utah 31

\section{Tables}

1. Range and mean values for porosity and hydraulic conductivity from soils and Navajo Sandstone core samples collected near the North Dam of Sand Hollow Reservoir, Utah

2. Specific-capacity values for Washington County Water Conservancy District, Utah, production wells

3. Calibrated hydraulic properties for parameters within the model domain for the Hurricane Bench area, Utah. 


\section{Conversion Factors}

Inch/Pound to SI

\begin{tabular}{|c|c|c|}
\hline Multiply & By & To obtain \\
\hline \multicolumn{3}{|c|}{ Length } \\
\hline foot (ft) & 0.3048 & meter $(\mathrm{m})$ \\
\hline mile (mi) & 1.609 & kilometer (km) \\
\hline \multicolumn{3}{|c|}{ Area } \\
\hline acre & 4,047 & square meter $\left(\mathrm{m}^{2}\right)$ \\
\hline acre & 0.004047 & square kilometer $\left(\mathrm{km}^{2}\right)$ \\
\hline square mile $\left(\mathrm{mi}^{2}\right)$ & 2.590 & square kilometer $\left(\mathrm{km}^{2}\right)$ \\
\hline \multicolumn{3}{|c|}{ Volume } \\
\hline acre-foot (acre-ft) & 1,233 & cubic meter $\left(\mathrm{m}^{3}\right)$ \\
\hline \multicolumn{3}{|c|}{ Flow rate } \\
\hline acre-foot per month (acre-ft/mo) & 1,233 & cubic meter per month $\left(\mathrm{m}^{3} / \mathrm{mo}\right)$ \\
\hline acre-foot per year (acre-ft/yr) & 1,233 & cubic meter per year $\left(\mathrm{m}^{3} / \mathrm{yr}\right)$ \\
\hline cubic foot per second $\left(\mathrm{ft}^{3} / \mathrm{s}\right)$ & 0.02832 & cubic meter per second $\left(\mathrm{m}^{3} / \mathrm{s}\right)$ \\
\hline gallon per minute (gal/min) & 0.06309 & liter per second $(\mathrm{L} / \mathrm{s})$ \\
\hline inch per year (in/yr) & 25.4 & millimeter per year (mm/yr) \\
\hline \multicolumn{3}{|c|}{ Specific capacity } \\
\hline $\begin{array}{l}\text { gallon per minute per foot } \\
{[(\mathrm{gal} / \mathrm{min}) / \mathrm{ft}]}\end{array}$ & 0.2070 & liter per second per meter $[(\mathrm{L} / \mathrm{s}) / \mathrm{m}]$ \\
\hline \multicolumn{3}{|c|}{ Hydraulic conductivity } \\
\hline foot per day (ft/d) & 0.3048 & meter per day $(\mathrm{m} / \mathrm{d})$ \\
\hline \multicolumn{3}{|c|}{ Hydraulic gradient } \\
\hline foot per mile (ft/mi) & 0.1894 & meter per kilometer $(\mathrm{m} / \mathrm{km})$ \\
\hline \multicolumn{3}{|c|}{ Transmissivity* } \\
\hline foot squared per day $\left(\mathrm{ft}^{2} / \mathrm{d}\right)$ & 0.09290 & meter squared per day $\left(\mathrm{m}^{2} / \mathrm{d}\right)$ \\
\hline
\end{tabular}

Vertical coordinate information is referenced to North American Vertical Datum of 1988 (NAVD 88).

Horizontal coordinate information is referenced to North American Datum of 1983 (NAD 83).

Altitude, as used in this report, refers to distance above the vertical datum.

*Transmissivity: The standard unit for transmissivity is cubic foot per day per square foot times foot of aquifer thickness $\left[\left(\mathrm{ft}^{3} / \mathrm{d}\right) / \mathrm{ft}^{2}\right] \mathrm{ft}$. In this report, the mathematically reduced form, foot squared per day $\left(\mathrm{ft}^{2} / \mathrm{d}\right)$, is used for convenience.

Specific conductance is given in microsiemens per centimeter at 25 degrees Celsius $(\mu \mathrm{S} / \mathrm{cm}$ at $\left.25^{\circ} \mathrm{C}\right)$.

Concentrations of chemical constituents in water are given either in milligrams per liter (mg/L) or micrograms per liter ( $\mu \mathrm{g} / \mathrm{L})$. 


\section{Abbreviations}

CFCs chlorofluorocarbons

$\mathrm{Cl}: \mathrm{Br} \quad$ chloride-to-bromide ratio

CSS composite scaled sensitivity

USGS U.S. Geological Survey

WCWCD Washington County Water Conservancy District 


\title{
Numerical Simulation of Groundwater Movement and Managed Aquifer Recharge from Sand Hollow Reservoir, Hurricane Bench area, Washington County, Utah
}

\author{
By Thomas M. Marston and Victor M. Heilweil
}

\section{Abstract}

The Hurricane Bench area of Washington County, Utah, is a 70 square-mile area extending south from the Virgin River and encompassing Sand Hollow basin. Sand Hollow Reservoir, located on Hurricane Bench, was completed in March 2002 and is operated primarily as a managed aquifer recharge project by the Washington County Water Conservancy District. The reservoir is situated on a thick sequence of the Navajo Sandstone and Kayenta Formation. Total recharge to the underlying Navajo aquifer from the reservoir was about 86,000 acre-feet from 2002 to 2009. Natural recharge as infiltration of precipitation was approximately 16,800 acrefeet for the same period. Discharge occurs as seepage to the Virgin River, municipal and irrigation well withdrawals, and seepage to drains at the base of reservoir dams. Within the Hurricane Bench area, unconfined groundwater-flow conditions generally exist throughout the Navajo Sandstone. Navajo Sandstone hydraulic-conductivity values from regional aquifer testing range from 0.8 to 32 feet per day. The large variability in hydraulic conductivity is attributed to bedrock fractures that trend north-northeast across the study area.

A numerical groundwater-flow model was developed to simulate groundwater movement in the Hurricane Bench area and to simulate the movement of managed aquifer recharge from Sand Hollow Reservoir through the groundwater system. The model was calibrated to combined steady- and transientstate conditions. The steady-state portion of the simulation was developed and calibrated by using hydrologic data that represented average conditions for 1975. The transient-state portion of the simulation was developed and calibrated by using hydrologic data collected from 1976 to 2009. Areally, the model grid was 98 rows by 76 columns with a variable cell size ranging from about 1.5 to 25 acres. Smaller cells were used to represent the reservoir to accurately simulate the reservoir bathymetry and nearby monitoring wells; larger cells were used in the northern and southern portions of the model where water-level data were limited. Vertically, the aquifer system was divided into 10 layers, which incorporated the Navajo Sandstone and Kayenta Formation. The model simulated recharge to the groundwater system as natural infiltration of precipitation and as infiltration of managed aquifer recharge from Sand Hollow Reservoir. Groundwater discharge was simulated as well withdrawals, shallow drains at the base of reservoir dams, and seepage to the Virgin River. During calibration, variables were adjusted within probable ranges to minimize differences among model-simulated and observed water levels, groundwater travel times, drain discharges, and monthly estimated reservoir recharge. In general, the model adequately simulated water levels, and most simulated water levels were within $10 \mathrm{ft}$ of measured water levels. Simulated arrival times of environmental tracers were within the range of observed arrivals at nearby monitoring wells from 2003 to 2008. The total simulated drain discharge from 2002 to 2009 was 9,500 acre-ft. The total simulated recharge from Sand Hollow Reservoir between 2002 and 2009 was approximately 94,000 acre-ft. Predictive modeling revealed an average travel time of 800 years from 2009 for water recharged in Sand Hollow Reservoir to reach the Virgin River, with the earliest arrival occuring in 500 years.

\section{Introduction}

The Hurricane Bench area of Washington County, Utah, is an elevated bench, approximately 6 miles (mi) wide and $11 \mathrm{mi}$ long, extending south from the Virgin River near the town of Hurricane, Utah (fig. 1). The area is bounded by the Hurricane Fault on the east side and by the erosional extent of the Jurassic Navajo Sandstone and Kayenta Formation on the west and south sides. The Navajo Sandstone is as much as 2,000 feet (ft) thick beneath Hurricane Bench. The local groundwater system is in the Navajo Sandstone and Kayenta Formation, and water movement is from south to north. The aquifer is unconfined, and natural recharge to the groundwater system as infiltration of precipitation occurs in higher elevation areas to the south and in areas where the Navajo Sandstone is thinly covered or exposed. Discharge from the groundwater system occurs as natural seepage to the Virgin River and as withdrawals from municipal and irrigation wells. A small part of the Navajo Sandstone in the northeastern part of the Hurricane Bench study area is covered by surface-flood basalts.

Sand Hollow Reservoir is located in Sand Hollow basin within the Hurricane Bench area, about 10 mi east of St. George, Utah (fig. 1). The reservoir is an off-channel facility operated by the Washington County Water Conservancy 


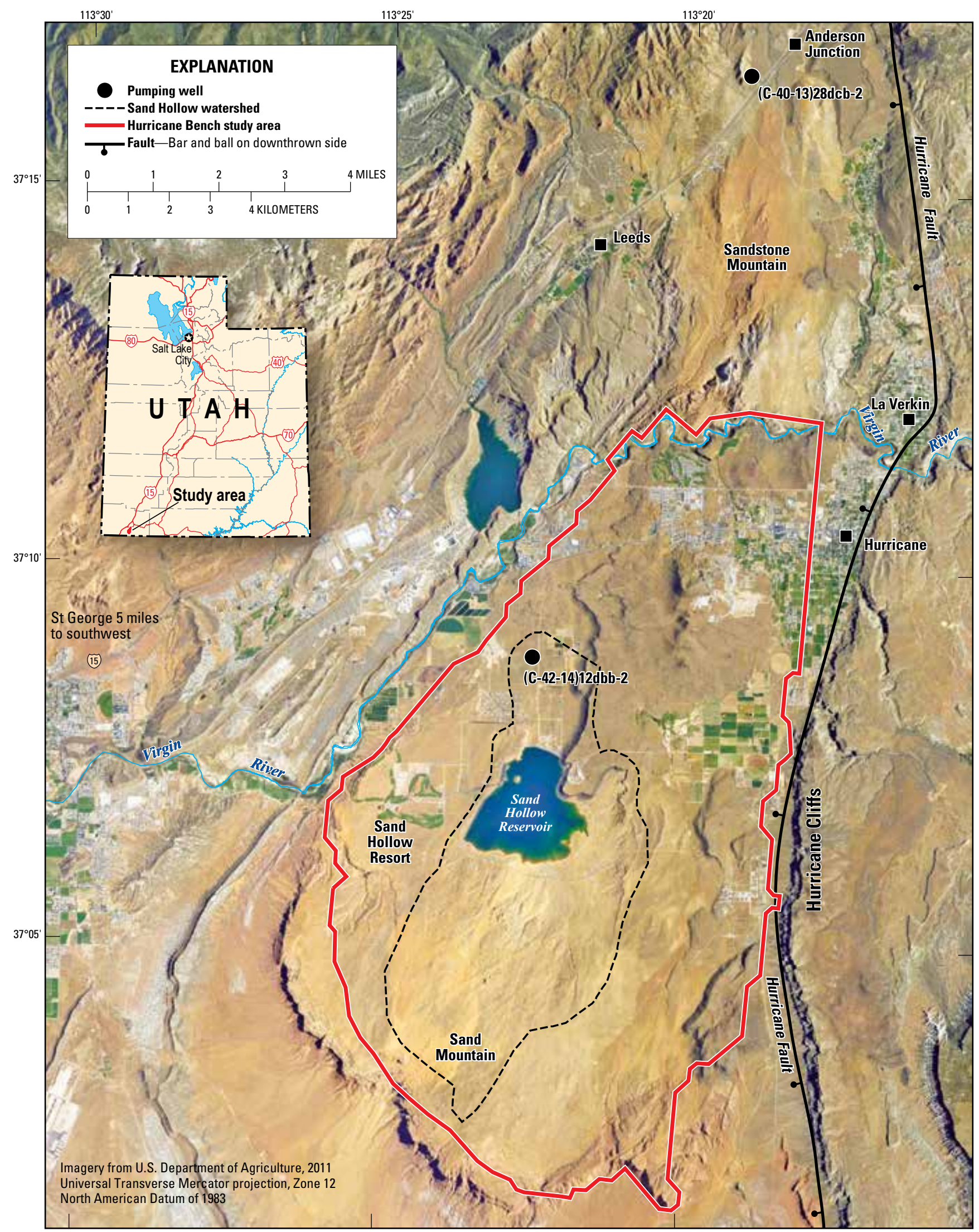

Figure 1. Hurricane Bench study area, Washington County, Utah. 
District (WCWCD) using water diverted from the Virgin River. The reservoir is operated for surface-water storage and managed recharge to the underlying aquifer system. The reservoir began filling in early 2002 and reached full pool in 2005 at an altitude of 3,060 ft. From 2005 to 2009, annual reservoir stage fluctuation below full pool was no greater than $20 \mathrm{ft}$ (Heilweil and Marston, 2011). The site of the reservoir is underlain by the Navajo Sandstone, which is partially covered by thin soils and eolian sands. Sand Hollow basin is located on a hinge line of a north-northeast trending syncline that forms a structural basin known as the Sand Mountain syncline (Hurlow, 1998).

The Hurricane Bench area has been the subject of interdisciplinary, cooperative investigations of groundwater hydrology and geochemistry since 1999. Previous reports document prereservoir groundwater conditions in Hurricane Bench prior to March 2002 (Heilweil and others, 2000); pre-reservoir vadosezone and groundwater studies in Sand Hollow (Heilweil and Solomon, 2004; Heilweil and others, 2006; Heilweil and others, 2007; Heilweil and McKinney, 2007), pond and trench infiltration studies adjacent to the reservoir (Heilweil and others, 2004; Heilweil and Watt, 2011), and pre- and post-reservoir groundwater conditions, water budgets, and estimates of groundwater recharge from the reservoir from March 2002 through December 2009 (Heilweil and others, 2005; Heilweil and Susong, 2007; Heilweil and others, 2009a; Heilweil and Marston, 2011). These reports also contain monitoring-well and production-well completion information, water-quality data, and precipitation data.

The purpose of this report is to describe the groundwater hydrology of the Hurricane Bench area and to present the construction, calibration, and projected results of a numerical simulation of the groundwater system in the Hurricane Bench area, including recharge from Sand Hollow Reservoir. A model was developed to estimate hydraulic properties of the Navajo Sandstone and Kayenta Formation, to test the conceptual understanding of the effects of managed aquifer recharge that commenced at Sand Hollow Reservoir in March 2002, and to project future movement of this recharge through the aquifer system. The flow-system concepts in the simulation are defined by previous referenced studies conducted in the Hurricane Bench area. This study is a cooperative effort between the WCWCD and the U.S. Geological Survey (USGS).

\section{Hydrogeologic Setting}

The Hurricane Bench area is underlain primarily by Navajo Sandstone that is either exposed at the surface or covered by a veneer of soil or surface-flood basalts (Hurlow, 1998; Heilweil and others, 2000, pl. 1). The Kayenta Formation underlies the Navajo Sandstone and is considered part of the groundwater system.

Although the total stratigraphic thickness of the Navajo Sandstone in this region is more than 2,000 ft, much of this has been eroded within the study area, and the sandstone pinches out to the west and south of Sand Hollow Reservoir.
The combined thickness of the Navajo Sandstone and Kayenta Formation is estimated to be about $2,900 \mathrm{ft}$ in the vicinity of Sand Hollow Reservoir, with $850 \mathrm{ft}$ attributed to the Kayenta Formation (Hurlow, 1998). Stratigraphic units in the Hurricane Bench area west of the Hurricane Cliffs have been displaced downward by more than $2,000 \mathrm{ft}$ as a result of vertical movement along the Hurricane Fault, which is located near the eastern boundary of the Hurricane Bench study area (fig. 1).

The Navajo Sandstone is characterized as well-sorted, fine-grained quartzose sandstone loosely cemented with calcite (Cordova, 1978). Predominant cross-bedding features reflect its eolian depositional environment (Hurlow, 1998). Because the Navajo Sandstone in the study area is only loosely cemented and well sorted, it has relatively high porosity and permeability. The Kayenta Formation underlies the Navajo Sandstone and contains some sandstone layers with similar permeability to the Navajo Sandstone separated by less permeable layers of siltstone. The interbedded siltstone layers of the Kayenta Formation likely inhibit vertical movement of water. The Jurassic Moenave Formation, consisting primarily of siltstone, underlies the Kayenta Formation and is considered less permeable than either the Navajo Sandstone or the Kayenta Formation.

In response to observations made by the WCWCD in 2004 regarding the large range of production rates in wells completed in the Navajo Sandstone (100 to 2,000 gallons per minute (gal/min)), a study was conducted to produce detailed fracture maps of the Navajo Sandstone in the area near Sand Hollow Reservoir (P.D. Rowley, Geologic Mapping, Inc., unpub. data, 2004). The results of this study showed many fracture zones associated with small faults that trend northnortheast in the east-central portion of the study area (fig. 2). Two of these fracture zones were documented in a trench excavated parallel to the North Dam of Sand Hollow Reservoir (Heilweil and Solomon, 2004). Another zone of fracturing was located on the northeast side of the reservoir. A previous study by Hurlow (1998) investigated fracture density for a larger region of the Navajo Sandstone that included the Hurricane Bench. Results of this study indicated that the area between Sandstone Mountain and the Virgin River, just north of the Hurricane Bench area (fig. 1), is highly fractured, with fracture density decreasing to the south toward Sand Mountain.

\section{Aquifer Properties}

\section{Navajo Sandstone and Overlying Soils}

Near the North Dam of Sand Hollow Reservoir, 14 soil samples, 4 shallow weathered sandstone core samples, and 13 deeper non-weathered sandstone core samples were collected and analyzed for hydraulic conductivity and porosity (Heilweil and others, 2004; table 1). The porosity of 14 local soil samples collected near the North Dam of Sand Hollow Reservoir ranged from 29 to 45 percent (Heilweil and others, 2004). These soils commonly overlie the Navajo Sandstone in low-lying areas of the study area. Laboratory measurements of saturated hydraulic conductivity of these soil samples ranged 


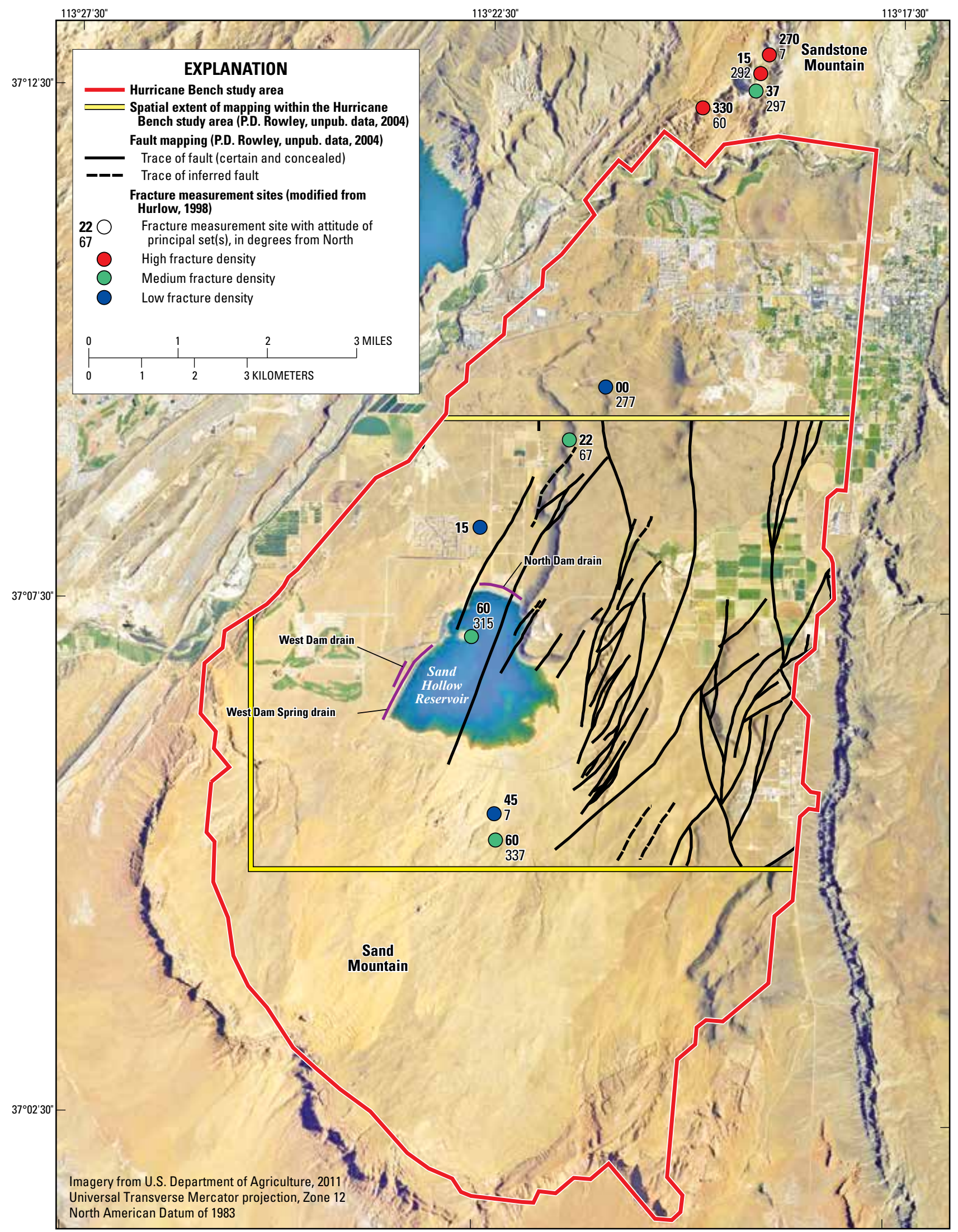

Figure 2. Bedrock fractures and faults in the Hurricane Bench area, Utah. 
from 0.01 to 0.2 foot per day ( $\mathrm{ft} / \mathrm{d}$ ). The porosity of four shallow (about 3.2-feet depth), weathered sandstone core samples collected at the same site ranged from 20 to 26 percent, and the saturated hydraulic conductivity ranged from 0.33 to $0.76 \mathrm{ft} / \mathrm{d}$. The porosity of 13 deeper (6.5 to 62 -foot depth), non-weathered sandstone core samples from the same trench ranged from 20 to 27 percent, and the saturated hydraulic conductivity ranged from 0.03 to $1.4 \mathrm{ft} / \mathrm{d}$ (Heilweil and others, 2004). Cordova (1978, table 3 ) reported an effective porosity of about 17 percent from laboratory analysis of 12 sandstone samples from selected outcrops in and around the study area. The average effective porosity from the two samples collected within the study area was 13.5 percent.

An aquifer test conducted at Winding Rivers Corporation well (C-42-14)12dbb-2 in the Hurricane Bench area, approximately $5 \mathrm{mi}$ southwest of Hurricane (fig. 1), yielded a saturated horizontal hydraulic conductivity of 0.8 to $2.2 \mathrm{ft} / \mathrm{d}$, on the basis of an assumed aquifer thickness of $1,350 \mathrm{ft}$ and $500 \mathrm{ft}$, respectively, in the calculation (Heilweil and others, 2000). Transmissivity and storage-coefficient values from this test were 1,075 feet squared per day $\left(\mathrm{ft}^{2} / \mathrm{d}\right)$ and 0.002 , respectively. Results of an aquifer test conducted at the WCWCD well (C-40-13)28dcb-2 in Anderson Junction, just north of the study area, indicated that fracture-related anisotropy can strongly influence directional permeability within the Navajo Sandstone. The hydraulic conductivity from this test ranged from 1.3 to $32 \mathrm{ft} / \mathrm{d}$ (Heilweil and others, 2000). The lower permeability is characteristic of unfractured sandstone, whereas higher permeability is characteristic of preferential flow along fractures.

Many of the higher production-rate wells operated by WCWCD are located in or near fracture zones. The specific capacity calculated for $13 \mathrm{WCWCD}$ production wells ranged from 0.4 to 6.1 gallons per minute per foot $((\mathrm{gal} / \mathrm{min}) / \mathrm{ft})$ (table 2). Specific capacity of a well is indicative of transmissivity. Generally, wells with large values of specific capacity are located near mapped fracture zones (fig. 2 and 3, wells 1, 21 , and 23), and wells with small values of specific capacity are in areas where no fractures are mapped (fig. 2 and 3, wells 3 and 17). There are also wells that are located near fracture zones (fig. 2 and 3, wells 2, 8, 9, 18, 19, 20, and 22) that have low to intermediate values of specific capacity.

No aquifer testing has been done to determine vertical hydraulic conductivity of the Navajo Sandstone within the study area. Horizontal and vertical hydraulic-conductivity values determined from laboratory analyses of Navajo Sandstone samples within the Upper Colorado River Basin were compiled by Weigel (1987, table 5). The averages for vertical and horizontal hydraulic conductivity of 24 samples were about $0.8 \mathrm{ft} / \mathrm{d}$ and $1.1 \mathrm{ft} / \mathrm{d}$, respectively. The ratio of vertical to horizontal laboratory-determined hydraulic-conductivity values for the 24 pairs of samples ranged from 0.13 to 2.7 , averaging about 0.4 . It is possible, however, that these discrete core samples do not accurately represent the bulk vertical hydraulic conductivity or vertical-to-horizontal anisotropy ratios for the Navajo Sandstone within the study area. The lowest vertical hydraulic conductivity in a layered sedimentary formation controls the overall vertical hydraulic conductivity of that formation. Therefore, it is likely that in some parts of the Navajo Sandstone, the vertical movement of groundwater could be more restricted than is indicated by the average of the laboratory-determined values. Lower overall vertical hydraulic-conductivity values and vertical-to-horizontal hydraulicconductivity ratios can result from thin, low-permeability horizontal layers that consist of fine-grained interdunal deposits

Table 2. Specific-capacity values for Washington County Water Conservancy District, Utah, production wells.

[WCWCD, Washington County Water Conservancy District; (gal/min)/ft, gallons per minute per foot]

\begin{tabular}{cc}
\hline WCWCD Well Number & Specific Capacity, in $(\mathbf{g a l} / \mathbf{m i n}) / \mathbf{f t}$ \\
\hline Well 1 & 5.20 \\
\hline Well 2 & 1.27 \\
\hline Well 3 & 1.20 \\
\hline Well 8 & 2.01 \\
\hline Well 9 & 2.27 \\
\hline Well 17 & 0.40 \\
\hline Well 18 & 2.52 \\
\hline Well 19 & 2.20 \\
Well 20 & 3.23 \\
Well 21 & 6.13 \\
Well 22 & 1.55 \\
\hline Well 23 & 4.18 \\
\hline
\end{tabular}

Table 1. Range and mean values for porosity and hydraulic conductivity from soils and Navajo Sandstone core samples collected near the North Dam of Sand Hollow Reservoir, Utah.

[ft, feet; ft/d, feet per day; $\cong$, approximately equal to]

\begin{tabular}{|c|c|c|c|c|c|c|}
\hline Sample type & $\begin{array}{l}\text { Depth of sample, } \\
\text { in ft below land } \\
\text { surface }\end{array}$ & Number of samples & $\begin{array}{l}\text { Range of porosity, } \\
\text { in percent }\end{array}$ & $\begin{array}{l}\text { Arithmetic mean of } \\
\text { porosity, in percent }\end{array}$ & $\begin{array}{l}\text { Range of saturated } \\
\text { hydraulic conduc- } \\
\text { tivity, in ft/d }\end{array}$ & $\begin{array}{l}\text { Geometric mean of } \\
\text { saturated hydraulic } \\
\text { conductivity, in } \mathrm{ft} / \mathrm{d}\end{array}$ \\
\hline Soil & Land surface & 14 & $29-45$ & 39 & $0.01-0.20$ & 0.07 \\
\hline $\begin{array}{l}\text { Weathered sand- } \\
\text { stone }\end{array}$ & $\cong 3.2$ & 4 & $20-26$ & 22 & $0.33-0.76$ & 0.56 \\
\hline Sandstone & $6.5-62$ & 13 & $20-27$ & 24 & $0.03-1.4$ & 0.33 \\
\hline
\end{tabular}






Figure 3. Monitoring wells, production wells, irrigation wells, and drains in the Hurricane Bench area, Utah. 
or have greater cementation than within the zone sampled for laboratory analyses. Conversely, vertical fracturing would increase the vertical hydraulic conductivity and vertical-tohorizontal hydraulic-conductivity ratios for the aquifer above the laboratory ratios.

\section{Kayenta Formation}

No aquifer testing has been done in or near the study area to determine the horizontal hydraulic conductivity, vertical hydraulic conductivity, or storage properties of the Kayenta Formation. A study conducted by Cordova and others (1972, table 11) reported a horizontal hydraulic-conductivity value of $1 \mathrm{ft} / \mathrm{d}$ on the basis of specific-capacity data from a well in St. George screened in the Kayenta Formation. The storage coefficient estimated from the specific-capacity data was 0.006 (Cordova and others, 1972, table 11). Estimated horizontal hydraulic conductivity from slug tests in the Kayenta Formation near Sheep Springs, about 2 mi northwest of St. George, ranged from 0.1 to $0.6 \mathrm{ft} / \mathrm{d}$ (Jensen and others, 1997).

Horizontal and vertical hydraulic-conductivity values have been determined from laboratory analysis of Kayenta Formation samples within the Upper Colorado River Basin, Utah, and Colorado (Weigel, 1987, table 5). The average horizontal hydraulic-conductivity value of 12 core samples was about $0.5 \mathrm{ft} / \mathrm{d}$ and ranged from $8.2 \times 10^{-4}$ to $1.4 \mathrm{ft} / \mathrm{d}$. The vertical hydraulic-conductivity values of two samples were $8.2 \times 10^{-4} \mathrm{ft} / \mathrm{d}$ and $0.5 \mathrm{ft} / \mathrm{d}$. The ratios of vertical-to-horizontal hydraulic conductivity for these two samples were 0.36 and 1.0 , respectively. The large range in values could be caused by the alternating siltstone, silty mudstone, and sandstone layers within the formation. As with laboratory analyses of core samples from the Navajo Sandstone, it is possible that these discrete vertical samples do not accurately represent the bulk hydraulic conductivity or vertical-to-horizontal anisotropy ratios for the Kayenta Formation. Also, hydraulic properties of the Kayenta could vary regionally between the Upper Colorado River Basin and the central Virgin River basin.

\section{Groundwater Conditions and Movement}

Groundwater in the Navajo Sandstone and Kayenta Formation generally is unconfined in the Hurricane Bench area. Prior to filling of the reservoir in 2002, water levels were higher south of the reservoir site and lower north of the reservoir site. Groundwater generally moved northward from Sand Mountain, which has the highest estimated rates of recharge from precipitation in Sand Hollow basin (Heilweil and McKinney, 2007). Horizontal hydraulic gradients, calculated by dividing the difference in water-level altitudes between two points by the distance separating these locations, indicated an average hydraulic gradient of about $0.006 \mathrm{ft} / \mathrm{ft}(30 \mathrm{ft} / \mathrm{mi})$ during 2001 in the vicinity of the reservoir site (fig. 4). The groundwater was intercepted primarily by irrigation wells located farther north of the reservoir site, although water levels measured in 1996 and 1997 in the northern part of Hurricane Bench indicated that some groundwater moved toward the Virgin River
(Heilweil and others, 2000). Water-level altitudes indicated that groundwater does not flow from the higher-altitude Pine Valley Mountains to the north, under the Virgin River and the Hurricane Bench area. The substantial offset of the Navajo Sandstone and Kayenta Formation, along with fine-grained fault gouge associated with the Hurricane Fault, likely restricts groundwater flow across the fault. The Hurricane Fault juxtaposes the Navajo Sandstone with the Permian Queantoweap Sandstone and Pakoon Formation, and the Pennsylvanian Callville Limestone (Hurlow, 1998). The hydrologic properties of these units are locally unknown.

One-time measurements of groundwater levels were made at monitoring well (C-42-13)18bcb-1 in 1958, monitoring well (C-42-14)25adc-2 in 1959, and monitoring well (C-42-13)6bac-1 in 1975 (fig. 3). Water levels were measured annually from 1971 to 2009 at monitoring well (C-42-14)12dbb-1 (fig. 5; Burden and others, 2010). Water levels were measured monthly at monitoring wells WD 1 through WD 5 and WD RJ from 1995 through 2009; water levels were measured monthly at WD 6 through WD 14 from mid-2001 through 2009; and water levels were measured monthly at WD 15 through WD 20 during the latter half of 2009 (fig. 3). Prior to 2002, water-level fluctuations in Sand Hollow generally were less than $10 \mathrm{ft}$, except at monitoring wells WD 1 and WD 2, which showed decreased water levels caused by groundwater withdrawals from nearby Well 9 during 2000 and 2001. Historical water levels from 1958 to 1975 at well (C-42-14)25ada-1 indicated a depth to water directly beneath the reservoir site of about $100 \mathrm{ft}$ and depth to water in wells located north of the reservoir from 30 to $100 \mathrm{ft}$. Prior to 2002 , depth to the water table south, east, and west of the reservoir site ranged from about 50 to $150 \mathrm{ft}$ below land surface. The substantial vadose-zone thickness represented a large volume available to store managed aquifer recharge.

Filling of Sand Hollow Reservoir began in March 2002. The reservoir stage rose from about 2,980 ft above sea level in March 2002 to a maximum of about 3,060 ft in May 2006, when the reservoir was first filled to capacity. The reservoir stage receded to about 3,040 ft in December 2007 and then fluctuated between about 3,040 and 3,060 ft during 2008 and 2009. The topographically lowest part of the reservoir bottom, adjacent to the North Dam, was inundated with surface water in 2002 and 2003. As the reservoir continued to fill from 2004 through 2006, the areal extent of surface water increased toward the south in a line roughly perpendicular to the North Dam. The monitoring wells nearest the northern side of the reservoir, therefore, were the first to show water-level responses and hydraulic connection with the reservoir. Water levels in wells WD 1,2, 6, and 9 rose rapidly beginning in the spring of 2002. Water levels in wells WD 3 and WD 11, located farther south along the western side of the reservoir, began to rise rapidly in November 2002 and January 2003, respectively. Water levels in wells WD 10 and WD 12, located on the eastern side of the reservoir, and in wells WD 7 and WD 8, located along the southern side of the reservoir, began rising in the latter half of 2003. During 2004-09, water levels 


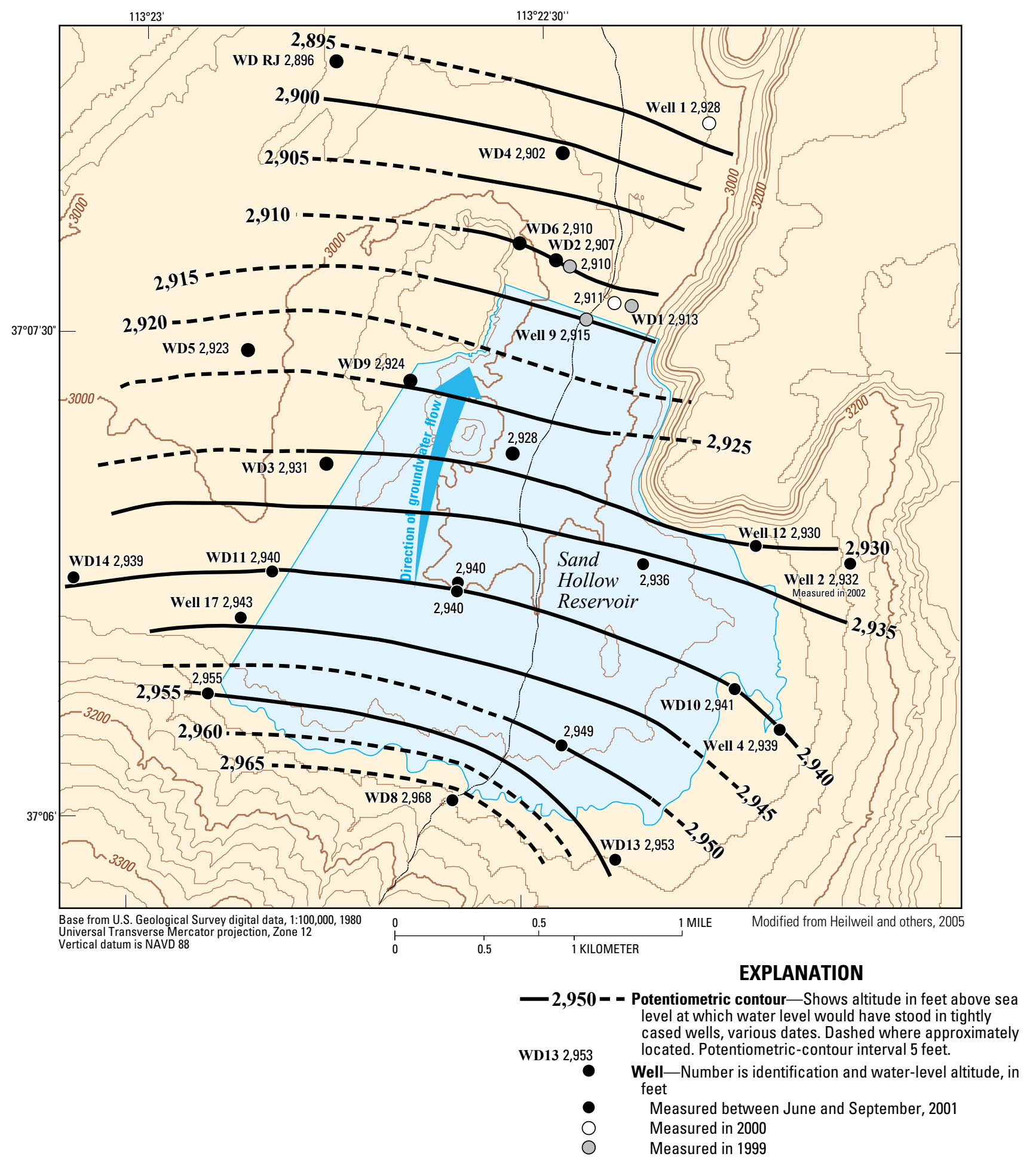

Figure 4. Potentiometric surface of the Navajo aquifer prior to completion of Sand Hollow Reservoir, Hurricane Bench area, Utah. 




Figure 5. Observed water levels from 1971 to 2009 at the (C-42-14)12dbb-1 monitoring well in the Hurricane Bench area, Utah.

in monitoring wells closer to the reservoir (WD 3, 7, 8, 9, 10,11 , and 12) generally fluctuated in response to changes in reservoir elevation. Water levels in the monitoring wells near the North Dam (WD 1, 2, and 6), however, rose sharply during the winters of 2003-04, 2004-05, 2005-06, and 2008-09 in association with the temporary cessation of pumping at nearby production wells 8 and 9 . Water levels in wells farther from the reservoir (WD 4, 5, RJ, 13, and 14) generally showed a more subdued rise in response to recharge beneath the reservoir. Water levels have been measured only since May 2009 in wells WD 15 through WD 20. Compared to pre-reservoir conditions, water levels in monitoring wells in the vicinity of Sand Hollow Reservoir increased by as much as $120 \mathrm{ft}$ by August 2009. Depth to water in these wells ranged from less than $5 \mathrm{ft}$ below land surface adjacent to the reservoir to about $90 \mathrm{ft}$ below land surface about $1 \mathrm{mi}$ north of the reservoir. In 2009 , the regional gradient between wells WD $9(3,041 \mathrm{ft}$ altitude) and WD RJ (2,909 ft altitude) was $0.021 \mathrm{ft} / \mathrm{ft}(105 \mathrm{ft} / \mathrm{mi})$, indicating more than a three-fold increase from pre-reservoir conditions. Potentiometric-contour values indicated that in 2009 groundwater was moving away from Sand Hollow Reservoir in all directions (fig. 6).

\section{Groundwater Budget}

\section{Recharge}

The only groundwater recharge in the Hurricane Bench area prior to the completion of Sand Hollow Reservoir was natural infiltration of precipitation. Since its completion in 2002 , seepage from the reservoir into the underlying groundwater system has become the primary form of recharge. Recharge rates in the study area were derived by Heilweil and others (2007) by using a least-squares linear regression between three surficial parameters (soil coarseness, topographic slope, and downgradient distance from outcrop) and the percentage of precipitation that becomes net infiltration based on environmental tracer data from excavations and boreholes at Sand Hollow Reservoir (Heilweil and others, 2006). Estimated recharge from precipitation for the Hurricane Bench study area is 2,100 acre-feet per year (acre-ft/yr) and averages 0.8 inches per year (in/yr), which is approximately 10 percent of precipitation. The highest recharge rates - greater than 2 $\mathrm{in} / \mathrm{yr}$ - are found in coarser soils in areas downgradient from sandstone outcrops at higher altitude, which receive more 


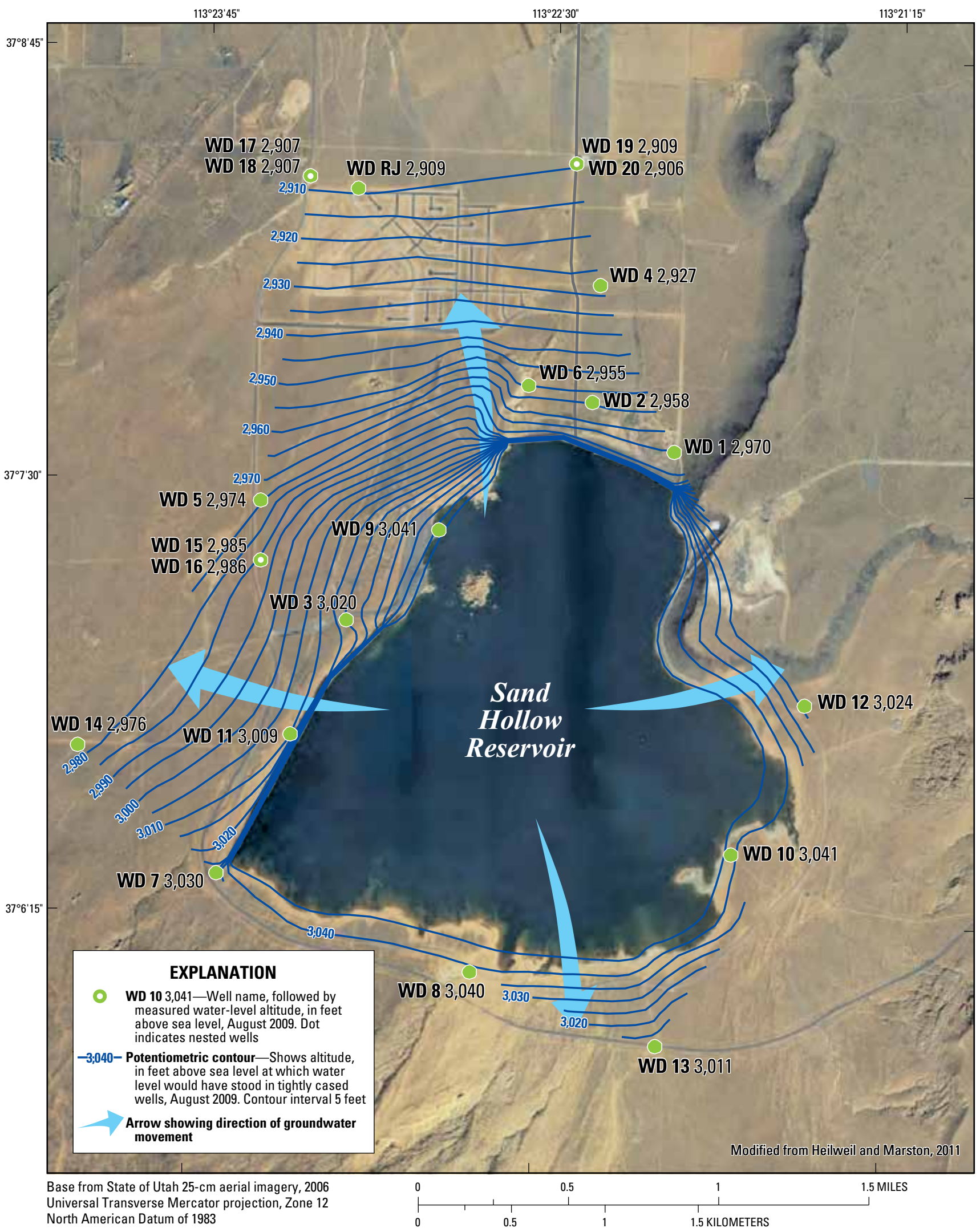

Figure 6. Potentiometric surface of the Navajo aquifer near Sand Hollow Reservoir, Hurricane Bench area, Utah, August 2009. 
precipitation. Moderate recharge rates of 10-50 millimeters per year $(\mathrm{mm} / \mathrm{yr})$ are found in upland areas with coarser soils, away from sandstone outcrops. The lowest recharge rates (less than $10 \mathrm{~mm} / \mathrm{yr}$ ) are characteristic of lower elevations beneath finer-grained soils not receiving runoff from sandstone outcrops. There are high-recharge areas south of Sand Hollow Reservoir by outcrops near Sand Mountain (fig. 1). The remaining upland area south of the reservoir, where outcrops of sandstone are less prevalent, has moderate recharge rates. The areas north and east of the reservoir have a mixture of low and moderate recharge rates.

A previous study by Heilweil and others (2000) indicated that groundwater recharge associated with applied irrigation water occurs east and northeast of the reservoir in the Hurricane Bench area; an irrigation-induced recharge of $1,050 \mathrm{acre}-\mathrm{ft} / \mathrm{yr}$ was estimated for this area. A later study by Heilweil and McKinney (2007), however, found that the same area likely receives little to no groundwater recharge because of the fine-grained sediment that is common to that area. The area northeast of the reservoir is also the location of Bench Lake, which was the source of clay material used in constructing the cores of both the North and West Dams of Sand Hollow Reservoir. The presence of large amounts of fine-grained material in the area typifies a low infiltration rate.

Reservoir recharge from March 2002 through December 2009 was calculated with a water-budget equation that accounts for surface-water inflows to and outflows from Sand
Hollow Reservoir, precipitation directly on the reservoir, evaporation from the reservoir, and changes in surface-water storage based on stage/bathymetry relations (Heilweil and Marston, 2011). Estimated monthly recharge rates beneath the reservoir ranged from about 0.001 to $0.43 \mathrm{ft} / \mathrm{d}$ between March 2002 and December 2009. Monthly reservoir recharge ranged from about 3,500 acre-ft to less than 100 acre-ft resulting in a total annual recharge range from about 5,000 acre feet (acre-ft) in 2008 to about 18,000 acre-ft in 2005 (fig. 7). Estimates of monthly recharge have an associated uncertainty of 6 to 14 percent.

Previous studies by Heilweil and others (2004), Heilweil and others (2009b), and Heilweil and Marston (2011) have investigated several flow-limiting processes that are likely inhibiting recharge through the reservoir bed sediments and underlying aquifer beneath Sand Hollow Reservoir. These include declining hydraulic gradients, the accumulation of silt and biofilms, and gas clogging. Although there is significant month-to-month variability in recharge rates, the trends in monthly recharge rates have been lumped into three periods: Period 1, March through June 2002, which had very high initial rates and then a steep decline as the vadose zone became saturated and the reservoir came into direct hydraulic connection with the aquifer; Period 2, mid-2002 through mid-2007, when recharge rates fluctuated but generally declined gradually; and Period 3, mid-2007 through 2009, when recharge rates were relatively constant (Heilweil and Marston, 2011, fig. 10).

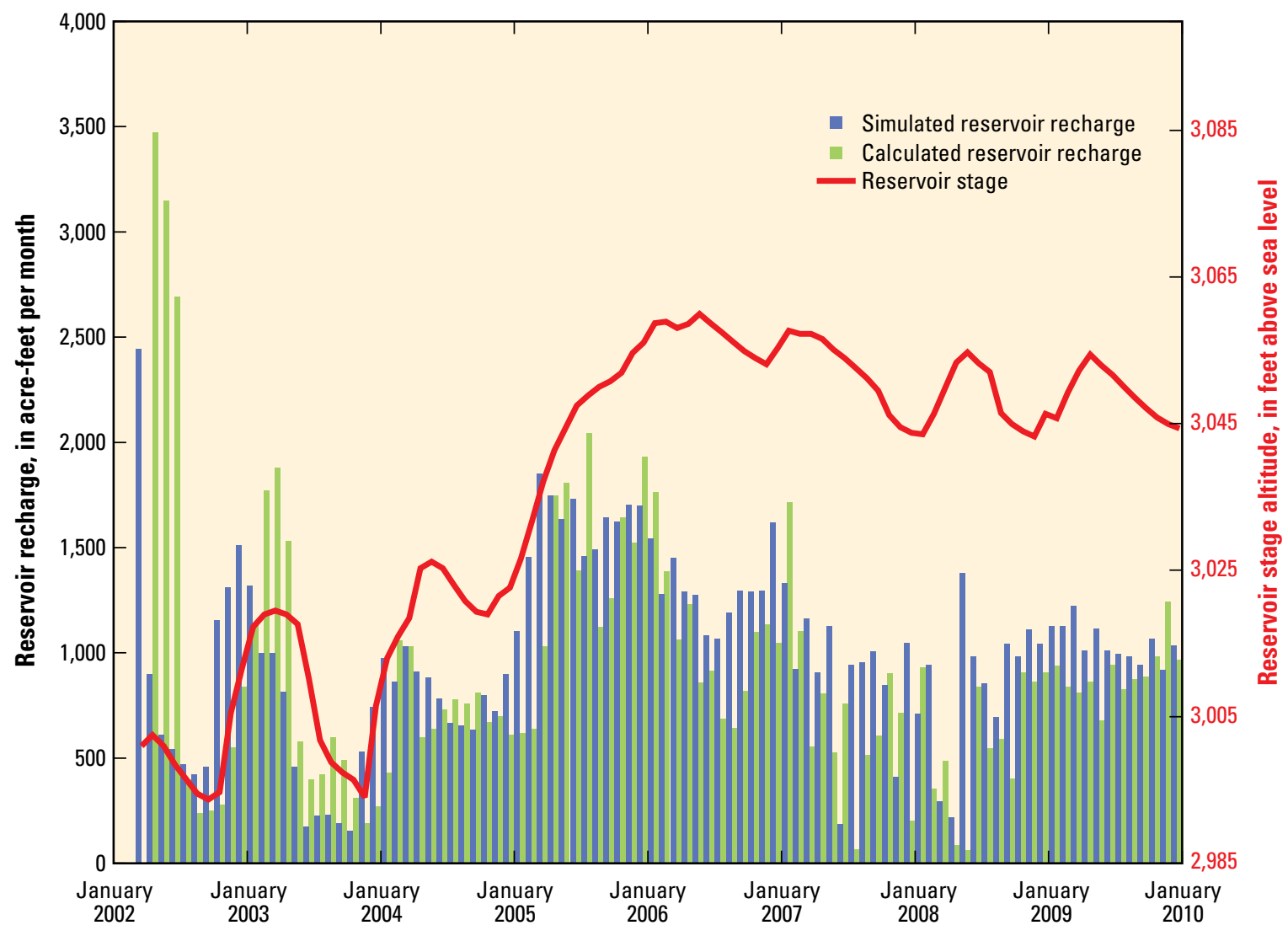

Figure 7. Estimated and simulated groundwater recharge from Sand Hollow Reservoir, Hurricane Bench area, Utah. 


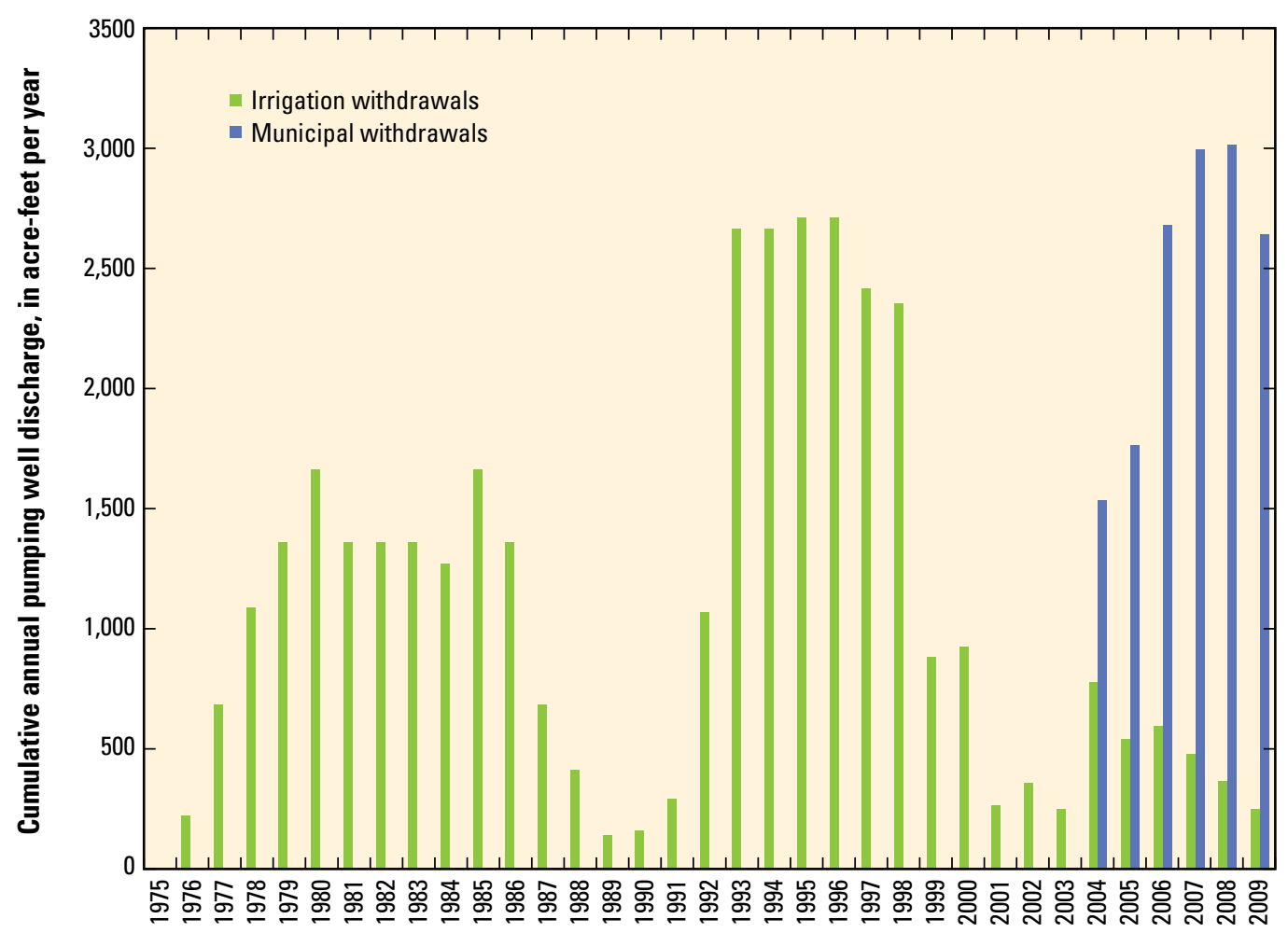

Figure 8. Estimated withdrawals from wells in the Hurricane Bench area, Utah, 1975-2009.

\section{Discharge}

The two predominant types of groundwater discharge from the Hurricane Bench area prior to the completion of Sand Hollow Reservoir were seepage to the Virgin River and well withdrawals. Natural groundwater discharge to the Virgin River takes place between the town of La Verkin and the erosional extent of the Navajo Sandstone approximately $3.5 \mathrm{mi}$ to the west. A previously published seepage study (Herbert, 1995) indicated a gain of about 7.2 cubic feet per second $\left(\mathrm{ft}^{3} / \mathrm{s} ; 5,200\right.$ acre- $\left.\mathrm{ft} / \mathrm{yr}\right)$ along this reach of the Virgin River from the Navajo Sandstone on both the north (Sandstone Mountain) and the south (Hurricane Bench) sides of the river. On the basis of estimates of recharge from precipitation (Heilweil and McKinney, 2007), it is assumed that $3 \mathrm{ft}^{3} / \mathrm{s}$ $(2,100 \mathrm{acre}-\mathrm{ft} / \mathrm{yr})$ or a little less than half of the estimated $7.2 \mathrm{ft}^{3} / \mathrm{s}$ of discharge to the Virgin River came from the Hurricane Bench prior to irrigation pumping in the mid-1970s. This includes the flow from one small spring (Berry Spring) with a reported discharge of $50 \mathrm{acre-ft/yr}$ in 1968 (Wilkowske and others, 1998). There was no reported spring discharge on the west side of the Hurricane Bench study area prior to the filling of Sand Hollow Reservoir. Although seepage to the Virgin River along the north part of the Hurricane Bench study area could increase in the future as a result of rising groundwater levels associated with reservoir recharge, increased seepage and spring discharge along the west side is unlikely because of the lower-permeability rocks (Moenave and Chinle
Formations) that have a nearly vertical dip associated with the Virgin River anticline (Heilweil and others, 2000, plate 1).

Prior to the mid-1970s, very few irrigation wells existed in the Hurricane Bench area; most water-rights claims were filed from the mid-1970s to the mid-1990s. Records of irrigationwell withdrawals are sparse, but an inventory of irrigationwell discharge was completed during the 1995 growing season. Well withdrawals from irrigation wells for years other than 1995 were estimated by using land-use data from Landsat imagery of the irrigated area north of Sand Hollow Reservoir during the months of June, July, or August for available years between 1975 and 2009. The values of annual estimated irrigation withdrawals were determined by multiplying the inventoried 1995 irrigation discharge with a ratio of irrigated-land coverage for each year between 1975 and 2009 to the irrigated-land coverage in 1995. All of the irrigation for this area is supplied by groundwater withdrawals; there are no surfacewater diversions. The uncertainty of estimation of withdrawals by using land use is likely greater than 20 percent. Well withdrawals for irrigation in the Hurricane Bench area increased rapidly from 1976 to 1980 and have been highly variable, peaking in the mid-1990s at about 2,700 acre-ft/yr (fig. 8). With the exception of two municipal wells supplying Sky Ranch, near the Hurricane Cliffs southeast of Sand Hollow, all of the pumping in the Hurricane Bench area for irrigation prior to filling of the reservoir in 2002 took place north of the reservoir. Well withdrawals for municipal use by the WCWCD began during January 2004; the pumping was 




Figure 9. Measured pumping and simulated discharge from the West Dam, West Dam Spring, and North Dam drains, Hurricane Bench area, Utah.

seasonal through 2005 and then remained relatively constant from 2006 through 2009. Total pumping from wells 1, 2, 8, 9,17 , and 21 generally ranged from 150 to 275 acre-feet per month (acre-ft/mo) during 2006-09 (Heilweil and Marston, 2011, fig. 3). Reported withdrawal values from the WCWCD have an associated uncertainty of at least 5 percent.

After reservoir completion, seepage to drains adjacent to Sand Hollow Reservoir became an additional type of discharge. Shallow groundwater has been discharging into drains parallel to the North and West Dams since 2003. The North Dam drain and the West Dam Spring drain were constructed in 20-ft-deep trenches in the Navajo Sandstone that extend parallel to each dam 3,000 ft and 6,000 ft in length, respectively. The second drain parallel to the West Dam, referred to as the West Dam drain, is a 10-ft-deep trench 1,500 ft in length farther downgradient of the West Dam Spring drain (fig. 3). Each of these drains operates as a French drain with a pump located at the lowest altitude in each of the trenches. Pumping by the WCWCD at these drains is based on saturation conditions and is not continuous. The sporadic nature of this pumping was demonstrated during 2008, when pumping rates varied from about 50 to more than 500 acre-ft/mo (fig. 9). Recorded drain pumping generally has an associated uncertainty of at least 5 percent.

\section{Numerical Simulation of Groundwater Flow}

A numerical model was developed to represent the groundwater system in the Hurricane Bench area. The primary objective of this model was to simulate managed aquifer recharge from Sand Hollow Reservoir and the subsequent movement of groundwater through the Hurricane Bench area. The numerical simulation represents initial steady-state hydrologic conditions in 1975 prior to (1) a period of increased irrigation-well withdrawals, which peaked in 1995, and (2) recharge from Sand Hollow Reservoir beginning in 2002. Data available from 1975 to 2009 include monitoring-well water levels and irrigation-well withdrawals. Additional data available from 2002 to 2009 include reservoir recharge, reservoir stage, pumping from drains parallel to the dams, municipal-well withdrawals, and tracer-based groundwater travel times. The "Model Construction" section of this report discusses the details of discretization, boundary conditions, and model parameters. The "Model Calibration" section discusses how the model was adjusted to match observed data. The "Model Accuracy" section discusses how adequately the model simulated the groundwater system. The "Model Projections" section (1) 
discusses simulated travel times for water originating at Sand Hollow Reservoir that ultimately will discharge to the Virgin River, (2) evaluates the change in groundwater storage, and (3) evaluates the long-term discharge to the Virgin River.

The groundwater-flow model was constructed with a modified version of MODFLOW-2005 that allows for temporal discretization of reservoir bed conductance and thickness in the Reservoir Package (Fenske and others, 1996). MODFLOW-2005 is the most recent version of the threedimensional, finite-difference, groundwater-flow model known as MODFLOW (Harbaugh, 2005). Sensitivity analysis and parameter estimation used to guide the construction and calibration of the model utilized UCODE_2005 (Poeter and others, 2005), which incorporates sensitivity analysis, parameter estimation, and uncertainty evaluation.

\section{Model Construction}

The model described in this report uses parameters and zones (Harbaugh, 2005) to define much of the input data. A parameter is a single value, which is given a name and determines the value of a variable in the finite-difference groundwater-flow equation at one or more model cells. Where parameters are used, the data value for a cell is either the parameter value or the calculated product of the parameter value and a cell multiplier, which could apply to many cells and can be described by using zones. Sensitivity analysis was used to refine model construction, parameter estimation, and model calibration.

Construction of the groundwater-flow model was accomplished by horizontally and vertically discretizing the hydraulic properties of the groundwater system, establishing model boundaries that depict conceptual hydrologic boundaries, and assigning model parameters to all stresses and aquifer properties except reservoir stage. Because managed aquifer recharge from Sand Hollow Reservoir is the dominant stress, model construction focused on being able to adequately simulate reservoir recharge and numerous water levels in proximity to the reservoir.

\section{Spatial and Temporal Discretization}

Areally, the model is discretized into a grid of rectangular cells and each cell has homogenous properties. Active cells, which delineate the lateral boundaries of the simulated groundwater system, generally correspond to the lateral extent of the Navajo Sandstone and Kayenta Formation in the Hurricane Bench area (fig. 10). The rectangular model grid contains 98 rows and 76 columns. Cell size is variable, and active cells range in size from about 1.5 to 25 acres (about 0.002 to 0.04 square mile $\left(\mathrm{mi}^{2}\right)$ ). Areas of small cell size represent the area beneath and surrounding Sand Hollow Reservoir. This more accurately simulates the reservoir bathymetry for the stageto-volume relation used by MODFLOW to determine if the reservoir is covering a cell and to provide finer discretization for the relatively large number of observation wells that are closely spaced near the reservoir. The model grid is oriented so that columns of cells are generally parallel to the dominant fracture direction in Sand Hollow, which is approximately 40 degrees from true north (Heilweil and Solomon, 2004).

Vertically, the model is divided into 10 layers. The seven upper layers equally divide the Navajo Sandstone, with thicknesses up to about $300 \mathrm{ft}$ in the northern part of the study area. The bottom three layers represent the Kayenta Formation and have a uniform thickness of about $280 \mathrm{ft}$ (fig. 11). Because the Navajo Sandstone is more eroded in the southern part of the active domain, layers in the Navajo Sandstone tend to thin from north to south. Because the Moenave Formation, consisting primarily of siltstone, underlies the Kayenta Formation, the bottom of the Kayenta is considered a no-flow boundary. The altitude of the bottom of the Navajo Sandstone was obtained from a structure-contour map of the Navajo Sandstone that included the Hurricane Bench area (Hurlow, 1998, plate 5A). The altitude of the bottom of the Kayenta Formation was set equal to $850 \mathrm{ft}$ lower than the bottom of the Navajo Sandstone (Hurlow, 1998; Heilweil and others, 2000). MODFLOW-2005 requires that layers be assigned as confined or convertible. Convertible layers automatically change from unconfined to confined conditions if the layer becomes fully saturated. A confined layer is one in which transmissivity is constant and specific storage instead of specific yield is used. In the Hurricane Bench area, full saturation of the uppermost part of the Navajo Sandstone results in standing water at the land surface rather than confined conditions. To prevent the model from simulating unrealistic confined conditions at land surface, the top of layer 1 was set to $200 \mathrm{ft}$ above land-surface altitude.

Temporally, the model was discretized into 26 annual stress periods from 1975 through 2000 and one 14 month stress period for 2001 and January and February 2002 because water levels and withdrawals were measured or estimated annually prior to the construction of the reservoir. Agricultural irrigation began in the late-1970s in the Hurricane Bench area. Because effects of nearby irrigation withdrawals can be seen in the long-term monitoring well (C-42-14)12dbb-1 after 1977 (fig. 5), the mid-1970s were considered to represent steadystate flow conditions prior to groundwater development for agriculture on Hurricane Bench and to represent the first and only steady-state stress period in the model (fig. 5). Ninetyfour monthly stress periods were used from March 2002 through December 2009, corresponding to initial filling and subsequent recharge from Sand Hollow Reservoir. Monthly hydrologic data for this period include water-level data from nearby monitoring wells, reservoir stage, calculated reservoir recharge, municipal-well withdrawals, and pumpage from drains (Heilweil and Marston, 2011).

\section{Aquifer Characteristics}

Unconfined conditions in the Navajo Sandstone are represented by the uppermost partially saturated cell for each location within the model. Fully saturated cells that lie beneath partially saturated cells represent portions of the Navajo Sandstone and Kayenta Formation that are simulated as confined. The hydraulic properties that control simulated water levels 


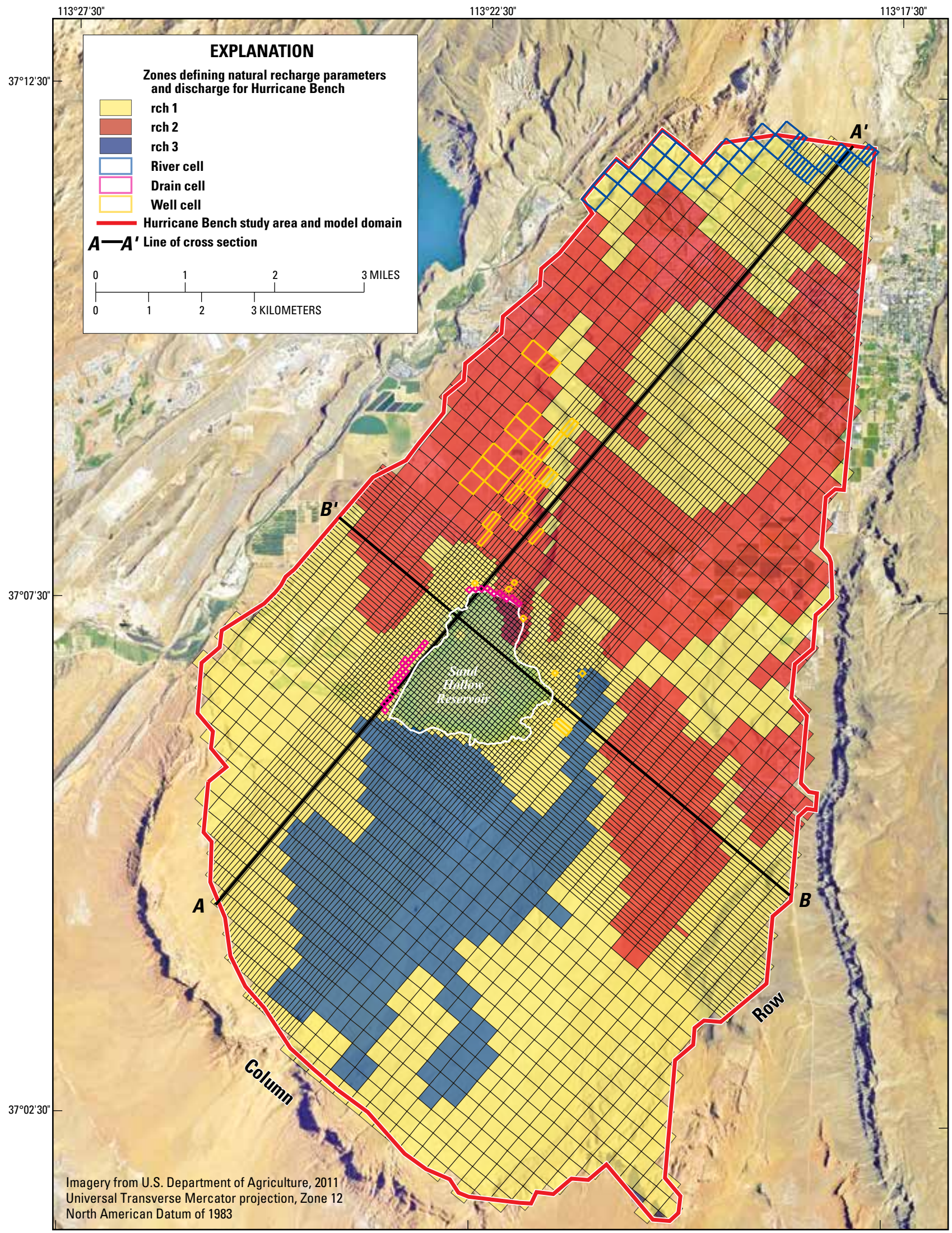

Figure 10. Model grid of the groundwater system and zones of low, medium, and high recharge from precipitation in the Hurricane Bench area, Utah. 

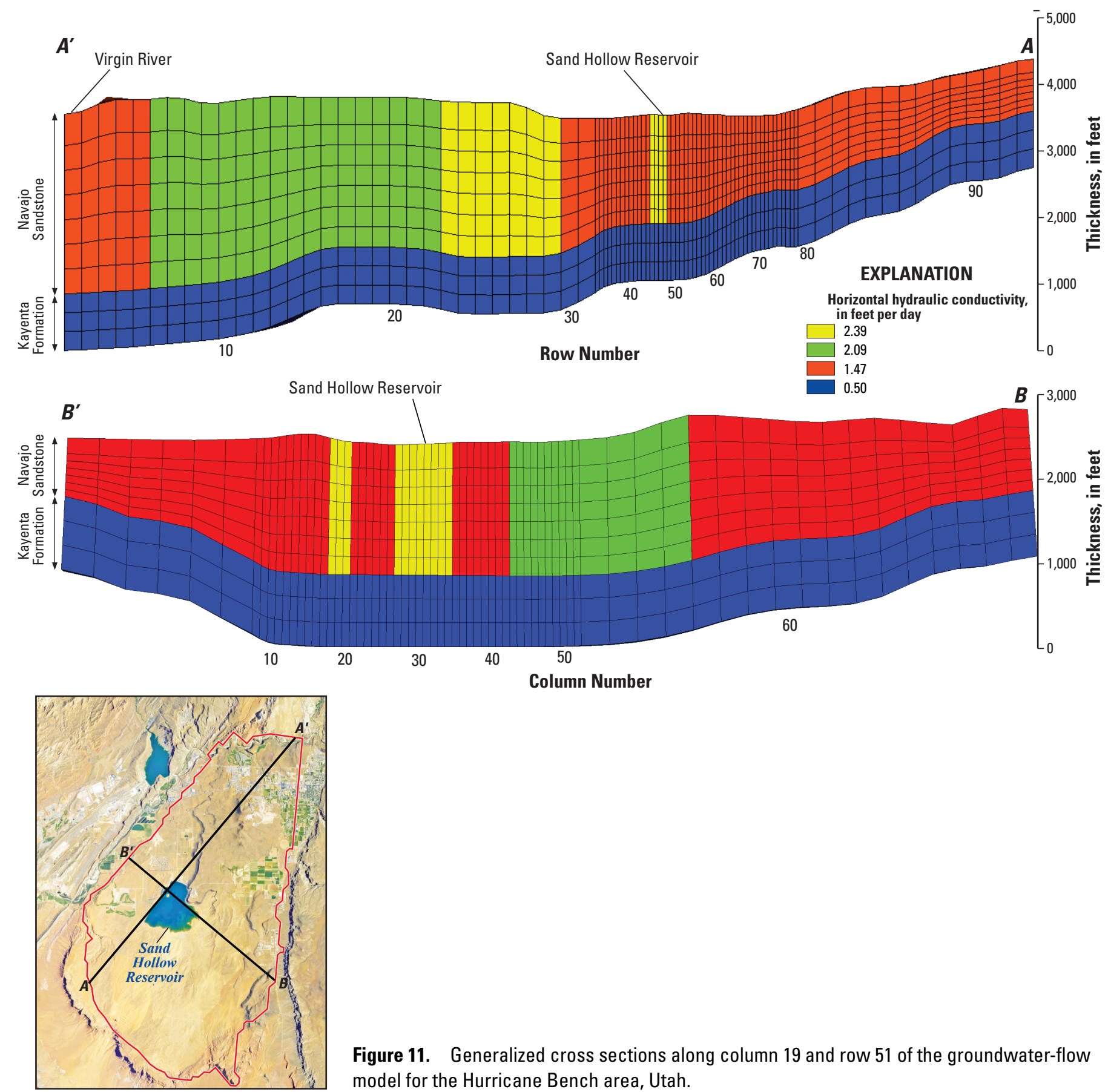

Figure 11. Generalized cross sections along column 19 and row 51 of the groundwater-flow model for the Hurricane Bench area, Utah.

are hydraulic conductivity and storage. Under unconfined conditions, storage is defined as specific yield; under confined conditions, it is defined as specific storage. Initial specified values for these parameters were within the ranges of hydraulic properties listed in table 3. During calibration, hydraulic conductivity of the Navajo Sandstone was delineated by zones (fig. 12) to allow more variability in the model domain to match areas of fractures and provide better calibration. The MODFLOW-2005 parameters for horizontal hydraulic conductivity for both the Navajo and Kayenta (hk1 through hk6 and kayentahk), horizontal anisotropy for the Navajo and Kayenta (hani1 through hani6 and hani_kynta), vertical hydraulic conductivity for the Kayenta (kayentavk), vertical anisotropy for the Navajo (vka1), specific yield for the Navajo (sy1), and specific storage for both the Navajo and Kayenta (ss1) are the actual values; no multiplier array was used to modify them. 


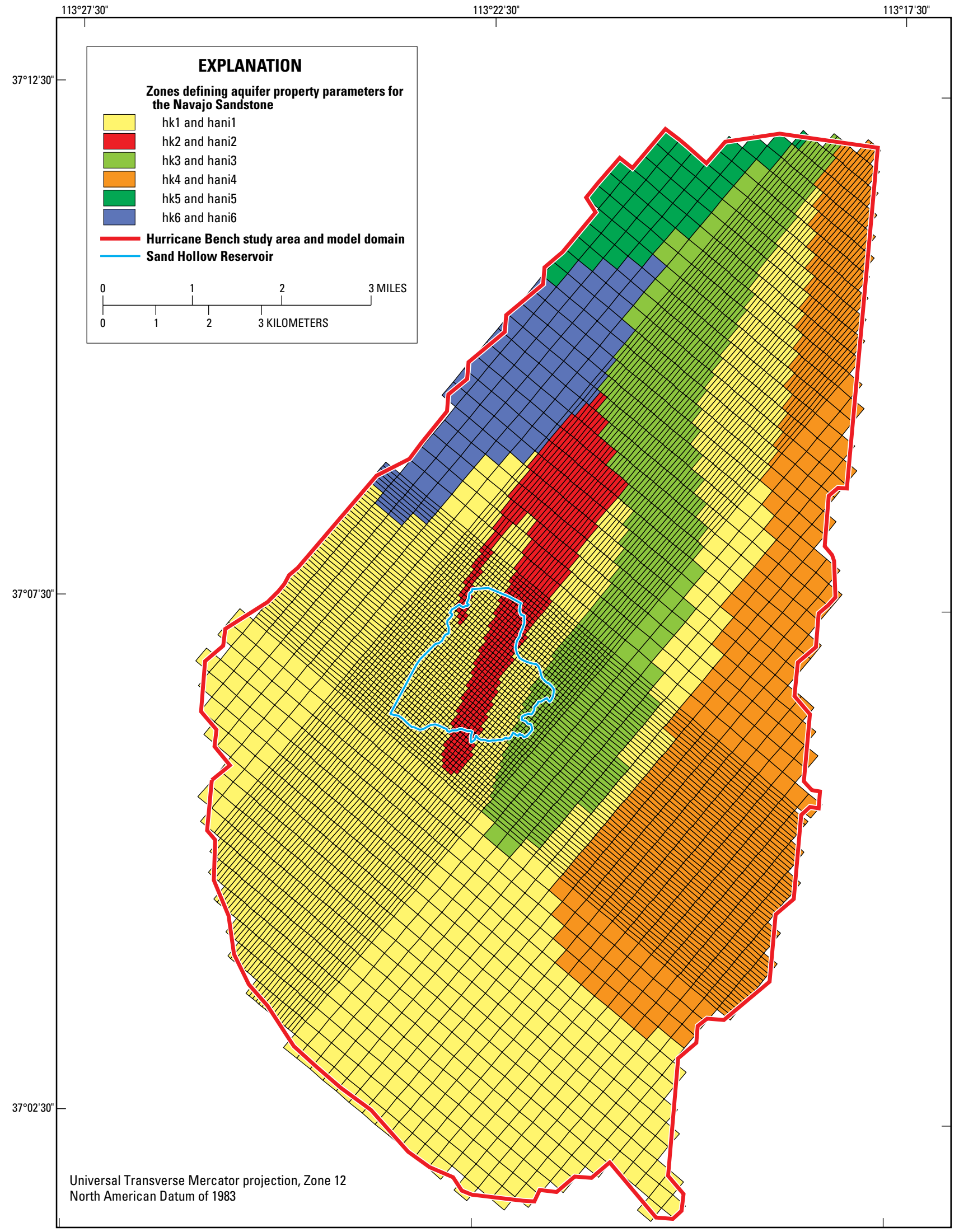

Figure 12. Hydraulic-conductivity zones of the Navajo Sandstone in the Hurricane Bench area, Utah. 
Table 3. Calibrated hydraulic properties for parameters within the model domain for the Hurricane Bench area, Utah.

[ft/day, feet per day; $\mathrm{ft}^{3} / \mathrm{ft}^{3}$, cubic foot of water per cubic foot of matrix; —, not applicable]

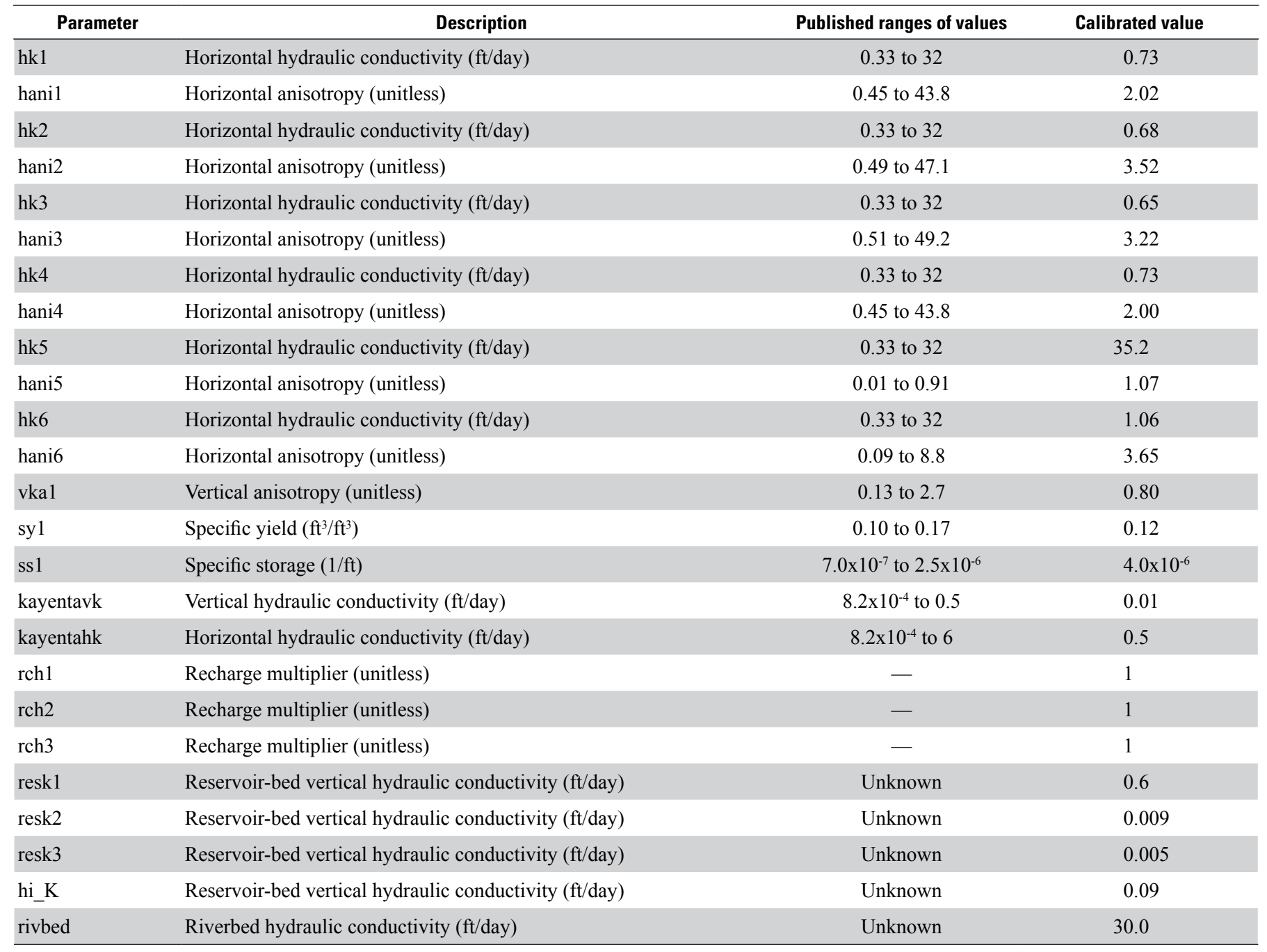

\section{Boundary Conditions}

The boundary conditions assigned in the groundwater-flow model mathematically represent the conceptual understanding of the boundaries in the actual groundwater system. These boundaries include no-flow boundaries, specified-flux boundaries, and head-dependent flux boundaries. These boundaries define the physical limits of the model and simulate recharge to and discharge from the groundwater system. No-flow boundaries are considered impermeable, and no flow is simulated across them. Specified-flux boundaries allow a specified rate of water through the boundary and are used to simulate some sources of recharge and discharge in the model. Headdependent flux boundaries simulate flow across the boundary proportional to the difference in heads across the boundary and are used to simulate some sources of recharge and discharge in the model.

\section{No-Flow Boundaries}

The entire outside border of the model domain is simulated as a no-flow boundary (fig. 10). The no-flow boundary on the east side of the model domain represents the mapped extent of the Navajo Sandstone and Kayenta Formation near the Hurricane Fault. The boundary on the southeastern, south, and western sides of the model domain is simulated as a no-flow boundary, representing the erosional extent of these geologic units and where no significant seepage occurs. Likewise, the northern side of the model domain is simulated as a no-flow boundary except in layer 1 , where groundwater can discharge to the Virgin River. 


\section{Recharge Boundaries}

Recharge from infiltration of precipitation was simulated as a specified-flux boundary with the Recharge Package (Harbaugh, 2005) and was applied to the topmost active layer. In this model, a base rate and multiplier array obtained from infiltration rates calculated in a study by Heilweil and McKinney (2007) were used to simulate natural recharge as a specified flux for the study area. MODFLOW-2005 allows the value of recharge flux to be defined as one or more parameters. Three recharge parameters and associated zones were defined as follows: rch1 corresponds to the zone of intermediate recharge, rch 2 corresponds to the zone of low recharge, and rch3 corresponds to the zone of high recharge (fig. 10). Recharge from precipitation was simulated as the product of the recharge parameter (base rate) and the natural recharge multiplier.

Recharge from Sand Hollow Reservoir was simulated as a head-dependent flux boundary with a modified version of the Reservoir Package (Fenske and others, 1996). The modified version allows for reservoir-bed thickness and hydraulic conductivity to vary temporally. This was needed because calibration to reservoir recharge, drain discharge, and water levels near the reservoir could not be achieved with non-varying reservoir bed hydraulic conductivity. The Reservoir Package computed flow from the reservoir to the groundwater system as a function of the simulated water level in the uppermost active cell, the water-level altitude of the reservoir (stage), and the reservoir-bed conductance. The Reservoir Package assumed that water moves from the reservoir to the aquifer under saturated conditions and water exchange between the reservoir and the groundwater system is instantaneous. The Reservoir Package was only active for cells within the specified area of potential inundation for Sand Hollow Reservoir and only when the reservoir stage exceeded reservoir-bed altitude. Fine spatial discretization (a small model-cell size relative to the size of the reservoir) was required to accurately represent the stage-to-active reservoir cell relation.

Data requirements for the Reservoir Package include reservoir stage, altitude of the bottom of the reservoir, thickness of the reservoir bed sediment, and hydraulic conductivity of the reservoir bed sediment. Reservoir stage for Sand Hollow Reservoir has been recorded daily since the reservoir began filling in March 2002 (Washington County Water Conservancy District, written commun., April 4, 2011). Detailed topographic mapping of the Sand Hollow Reservoir site conducted by RB\&G Engineering, Inc. (1994) prior to construction was used to establish the bottom altitude of the reservoir. The contour interval for reservoir bathymetry is $10 \mathrm{ft}$. Existing pre-reservoir sediment thickness was assumed to be $5 \mathrm{ft}$ for the entire reservoir on the basis of measurements made during excavation of the North and West Dams (Heilweil and others, 2007).

\section{Discharge Boundaries}

Simulated discharge from the groundwater system was to the Virgin River, the North Dam and West Dam drains, and to pumping wells. Discharge to the Virgin River was simulated as a head-dependent boundary with the River Package (Harbaugh, 2005). The River Package computes flow from the groundwater system as a function of groundwater levels in cells that coincide with the river boundary, the water level in the river (stage), and the riverbed conductance. The riverbed conductance is defined as a parameter in this model and represents the product of the hydraulic conductivity of the riverbed and the seepage area of the river cell. Because the river is known to gain groundwater in this area (Herbert, 1995) the river stage was set equal to the river bottom in the model. This prevents leakage from the river and minimizes the effects of local flow paths near the river.

Shallow groundwater discharge to drains at the foot of the North and West Dams of Sand Hollow Reservoir was simulated with the head-dependent Drain Package (Harbaugh, 2005). The Drain Package computes flow from the groundwater system as a function of groundwater levels in cells that contain the drain boundary, the altitude of the base of the drain, and the drain conductance. The drain conductance is defined as a parameter in this model. The three shallow drains at the base of the reservoir (West Dam Spring drain, West Dam drain, North Dam drain) are pumped sporadically, which induces a stress on the aquifer similar to a shallow well.

Discharge from both irrigation and municipal wells (fig. 8) was simulated as specified flux using the Well Package (Harbaugh, 2005). Two well parameters were defined in the model: one for irrigation wells and the other for municipal wells.

\section{Model Calibration}

The objective of the numerical groundwater-flow model calibration was to obtain a simulation that reasonably represents groundwater recharge, movement, discharge, and measured water levels in order to predict the movement of recharge from Sand Hollow Reservoir and to estimate the additional storage capacity of the underlying Navajo Sandstone and the long-term discharge to the Virgin River. Model calibration was accomplished by minimizing the sum of squared errors between simulated and observed data in UCODE-2005 (Poeter and others, 2005). During calibration, the numerical results were constrained by observed water levels, drain discharge, river discharge, reservoir recharge, and the groundwater travel times to monitoring wells from environmental tracer analyses. Observations utilized in the Observation Package in MODFLOW (Harbaugh, 2005) and UCODE (Poeter and others, 2005) for calibration are monitoring-well water levels, estimated monthly reservoir recharge, pumpage from drains (Heilweil and Marston, 2011), and discharge to the Virgin River in the steady-state stress period (Herbert, 1995). Environmental tracer arrival times were used for comparison to evaluate model performance (Heilweil and Marston, 2011). Calibration relied on both trial and error comparison and formal parameter estimation by regression using UCODE-2005 (Poeter and others, 2005).

Initially, all model parameters (table 3 ), except areal recharge and well parameters, were allowed to vary during regression. Recharge from precipitation was not allowed 
to vary because it had been defined by previous studies (Heilweil and McKinney, 2007). The well parameter for the WCWCD wells was not allowed to vary because withdrawal data supplied by the WCWCD for municipal wells were more accurate (within 5 percent) than other stresses in the model. The well parameter for the irrigation wells was never varied because the estimated withdrawals produced a good match with recorded long-term monitoring-well water levels in well (C-42-14)12dbb-1.

\section{Sensitivity Analysis}

Sensitivity analysis was used to evaluate the information provided by the observations for the estimation of all defined parameters, to eliminate insensitive parameters from the regression, and to determine areas where parameters could be further divided or combined. Sensitivity analysis for parameters in the model was carried out using UCODE-2005 (Poeter and others, 2005). For the Hurricane Bench area model, 31 parameters representing hydraulic properties, recharge, and well withdrawals were used; 14 of these were estimated by regression at some point during the calibration process, and 6 other parameters were adjusted by trial and error. Eleven parameters were assigned and not varied during calibration.

\section{Composite Scaled Sensitivities}

The sensitivity of observations to parameters was used to aid model calibration. Composite scaled sensitivity (CSS) can be used to evaluate whether available observations provide adequate information to estimate each parameter (Hill and others, 2000, p. 96) and can provide an overall view of the average amount that simulated values change in response to a 1-percent change in the parameter (Hill and Tiedeman, 2007, p. 50). The relative size of CSS values was used to assess the need for additional parameters and zones. Relatively large CSS values indicate that observations contain enough information to represent that aspect of the system in more detail, thereby justifying the use of additional parameters such as more hydraulic conductivity or recharge zones. A relatively small CSS value (about two orders of magnitude less than the largest CSS value) indicates that the observations provide insufficient information with which to estimate the parameter (Hill and Tiedeman, 2007, p. 50). After initial sensitivity analysis, parameters with small CSS values generally were assigned a fixed value or joined with a parameter with a similar value. The CSS values indicate that observations provide more information about natural recharge, hydraulic conductivity, and specific yield than about other model parameters, such as specific storage and riverbed conductance (fig. 13).



Figure 13. Composite scaled sensitivities for model parameters in the groundwater-flow model for the Hurricane Bench area, Utah. 
Sensitivity analysis and regression were based on weighted residuals between simulated and observed values. Because water-level and drawdown observations were more accurate than recharge and discharge observations, they had larger weights and, typically, larger weighted residuals. The weighting and the fact that water-level and drawdown observations were much more numerous and widely distributed than recharge and discharge observations in the numerical model caused them to have more influence on the parameters. As a result, some parameters that control recharge from the reservoir and discharge to the drains were adjusted outside of regression to more closely match those observations.

\section{Parameter Correlation Coefficient}

Parameter correlation coefficients were used to evaluate whether parameters can be estimated uniquely by regression (Hill and Tiedeman, 2007, p. 53). A correlation coefficient with an absolute value close to 1.00 indicates that the two parameters involved likely cannot be estimated uniquely. Generally, absolute values greater than 0.95 are cause for concern, but values as small as 0.85 are reported in UCODE output because these lower correlations can affect the uncertainty of parameter estimates. Where parameter correlation was high, the value of the correlated parameter with the smallest CSS was assigned a value and not adjusted during regression. One set of parameters (hk5 and hani5) in the model yielded a parameter correlation coefficient near 1.0; therefore, during regression, hani5 was set to 1.07 and not adjusted. This value, based on trial and error, was less than the other hani values $(2.0-3.52)$ because of the likely greater permeability along both 40- and 280-degree fracture orientations mapped by Hurlow (1998) just north of the study area near Sandstone Mountain (fig. 2).

\section{Influence Statistics}

The RESIDUAL_ANALYSIS program (Poeter and others, 2005) was used to calculate additional statistics useful for finding observation errors and model construction errors, and for highlighting changes in model construction that can lead to more realistic values of model parameters and better calibration. Two metrics of these are the Cook's D and DFBETAS statistics. The Cook's D statistic identified observations that, if omitted, would cause the greatest changes in estimated parameter values. The DFBETAS statistic identified observations that were influential in the estimation of each parameter (Poeter and others, 2005, p. 181). If nonlinear regression led to unreasonable parameter values in the Hurricane Bench model, or if regression statistics indicated that a parameter change improved one part of the model but made the fit worse in other areas, these statistics were used to make model changes.

\section{Nonlinear Regression}

Nonlinear regression was used to find parameter values that produce simulations that best fit the observations by adjusting parameter values to minimize the least-squares objective function by using weighted residuals. The fit between model simulated values and associated observations was quantified by using a weighted least-squares objective function (Hill and Tiedeman, 2007, p. 27-28). The weighting used in this objective function was based on observation errors presented in the "Groundwater Budget" section of this report and assumes that errors in the observations are uncorrelated.

\section{Parameter Adjustment and Final Values}

During model calibration, values of horizontal hydraulic conductivity and horizontal anisotropy of the Navajo Sandstone, and values of reservoir bed conductance, were changed by modifying both the distribution of parameters (assigning and adjusting spatial zones) and by changing parameter values. Vertical anisotropy of the Navajo Sandstone, specific yield, specific storage, and vertical hydraulic conductivity of the Kayenta Formation were modified only by changing parameter values; these parameters were not assigned spatial zones. Parameters for reservoir bed conductance were divided and refined even though the CSS values were not high (fig. 13). This achieved a better match between simulated water levels and observed water levels in some locations. Values of other parameters were not changed during calibration but are discussed in the following sections.

\section{Hydraulic Conductivity and Anisotropy}

Sensitivity analysis indicated that the observations provided enough information to represent the horizontal hydraulic conductivity of the Navajo Sandstone by using at least six zones (fig. 12) and 12 parameters (table 2), rather than one homogenous value. In addition to hydraulic conductivity, each zone of the Navajo Sandstone includes a parameter for horizontal anisotropy to simulate enhanced hydraulic conductivity along the dominant north-northeast trending fractures in the study area. Both the spatial distribution of the zones and the values of the horizontal hydraulic conductivity parameters were adjusted during model calibration to cause simulated water levels to more closely match observed water levels. The final adjusted horizontal anisotropy ratios ranged from 1.07 to 3.65 , resulting in hydraulic-conductivity values of 1.47 to $38 \mathrm{ft} / \mathrm{d}$ in the N 40 E direction (table 3). The adjusted vertical anisotropy (vka1) final value of 0.8 is within the known range of 0.13 to 2.7 (Heilweil and others, 2000) but implies that the Navajo Sandstone is more permeable in the vertical direction than in the horizontal direction (NW-SE) in the model. The final hydraulic property estimates from regression all lie near or within the previously published ranges of values. Horizontal hydraulic conductivity and anisotropy of the Navajo Sandstone in zone 1 of the model (hk1, hani1) are also very sensitive parameters because of the large size of this zone and its abundance of observations. Typically, this area would be split on the basis of its high degree of sensitivity, but it was left intact because it contains a large area where fractures have not been mapped because of soil cover. 
The northwestern portion of the model domain near the Virgin River has a simulated hydraulic conductivity that is more than an order of magnitude greater than the surrounding hydraulic conductivities. This condition is plausible because of the proximity of the area to Sandstone Mountain, an area known to be highly fractured and known to have hydraulicconductivity values of $32 \mathrm{ft} / \mathrm{d}$ on the basis of the Anderson Junction aquifer test.

Horizontal hydraulic conductivity for the Kayenta Formation was held constant at $0.5 \mathrm{ft} / \mathrm{d}$. This value was not adjusted because the associated parameter was insensitive to model observations. The value of this fixed parameter was based on previous work presented in the "Aquifer Properties" section of this report. The final calibrated vertical hydraulic-conductivity parameter for the Kayenta Formation was $0.01 \mathrm{ft} / \mathrm{d}$; values of simulated reservoir recharge were sensitive to this parameter based on trial and error adjustments. In this study, flux observations had a much greater uncertainty than head observations. As a result, UCODE indicated that this parameter was insensitive (fig. 14) because there was less weight assigned to flux observations than to head observations.

\section{Specific Yield and Specific Storage}

One specific yield parameter (sy1) was assigned for the Navajo Sandstone; this value applies to the uppermost saturated cell in the model at any given location. Under unconfined conditions that exist in the Navajo Sandstone in the Hurricane Bench area, specific yield was considered to be equal to effective porosity. One specific storage parameter (ss1) was defined, which represents fully saturated conditions in either the Navajo Sandstone or the Kayenta Formation. The value of both parameters was adjusted during model calibration. The final value of 0.12 for sy 1 was determined by regression and is within the range of reported effective porosity values of 0.10 to 0.17 for the Hurricane Bench area (table 3 ). The final value of $4.0 \times 10^{-6}$ per foot for ss 1 was assigned by trial and error because model observations did not provide enough information to estimate it (fig. 13). The assigned value was slightly greater than known values, which range from $7.0 \times 10^{-7}$ to $2.5 \times 10^{-6}$ per foot (Heilweil and others, 2000).

\section{Natural Recharge as Infiltration of Precipitation}

The model was very sensitive to the natural recharge parameters (rch1, rch2, rch3) prior to the completion of Sand Hollow Reservoir in 2002, but became less sensitive to these parameters when reservoir recharge dominated the system. Three parameters were assigned to simulate natural recharge as infiltration of precipitation. Each recharge parameter (rch1, rch2, rch3) was a multiplier value for an associated zoned area (fig. 10) representing intermediate, low, or high infiltration rates, respectively. Simulated water-level observations were very sensitive to rch1 and rch3 (fig. 13). None of the three parameters were adjusted, however, because of the relatively large amount of information available about infiltration in the basin (Heilweil and McKinney, 2007). All other parameter values determined in this model calibration were estimated on the assumption that estimated recharge from precipitation is correct. The resulting average natural recharge rates for each of the fixed parameter zones ( $\mathrm{rch} 1, \mathrm{rch} 2, \mathrm{rch} 3)$ were 20,8 , and $31 \mathrm{~mm} / \mathrm{yr}$, respectively. The annual total simulated natural recharge to the Hurricane Bench study area was approximately 2,100 acre-ft.

\section{Reservoir Recharge}

Initially, one parameter representative of the hydraulic conductivity of the reservoir bed was assigned to the spatial extent of the reservoir with a value equal to the average horizontal hydraulic conductivity of the Navajo Sandstone. Comparison of calculated reservoir recharge rates from 2002 to 2009 to simulated recharge from the reservoir by using one zone and one conductivity through time showed that simulated recharge was approximately 30 percent more than the estimated recharge of 86,000 acre-ft, however. To help improve the match between model-simulated and calculated recharge from Sand Hollow Reservoir, the reservoir bed conductance parameter was split into four parameters (resk1, resk2, resk3, and hi_K) and assigned to two different zones within the boundary of Sand Hollow Reservoir (fig. 14). These parameters were defined even though the CSS values were not high (fig. 13) because better matches were achieved with calculated reservoir recharge, and between simulated water levels and observed water levels in some locations. The reservoir-bed hydraulic-conductivity parameters (resk1, resk2, and resk3) that simulate clogging processes varied temporally, and all corresponded to a zone beneath the deepest part of the reservoir. The parameter hi_K did not vary temporally and corresponded to a higher permeability zone on the edge of the reservoir (fig. 14). This zone occupied the approximate perimeter of the reservoir and represented areas in the reservoir that were less likely to be subject to limiting processes, such as siltation either by their relatively steep grades and exposed bedrock or by the late date at which reservoir filling caused saturation. The zone that occupied the low flat-lying areas of the reservoir (fig. 14) was defined by three parameters. Reservoir-bed conductivity in this zone was defined as a time-variable value, where time-dependent conductivity values were linearly interpolated in three segments defined by three parameter values (resk1, resk2, and resk3) representing March 2002, August 2002, and July 2007, respectively. The first segment, between March 2002 and August 2002, represented the initial high rate of recharge; the middle segment, between August 2002 and July 2006, represented a period of generally decreasing rates of recharge; and the last segment, from July 2006 to December 2009 , represented a period of generally static calculated recharge rates (fig. 15).

\section{Drain and River Discharge}

Simulated discharge from the shallow drains was compared to reported pumping from the drains during model calibration. Three parameters (ndd, wdd, and wdsd) corresponding to the North Dam Drain, West Dam Drain, and combined West Dam and West Dam Spring Drains, respectively, were assigned a 


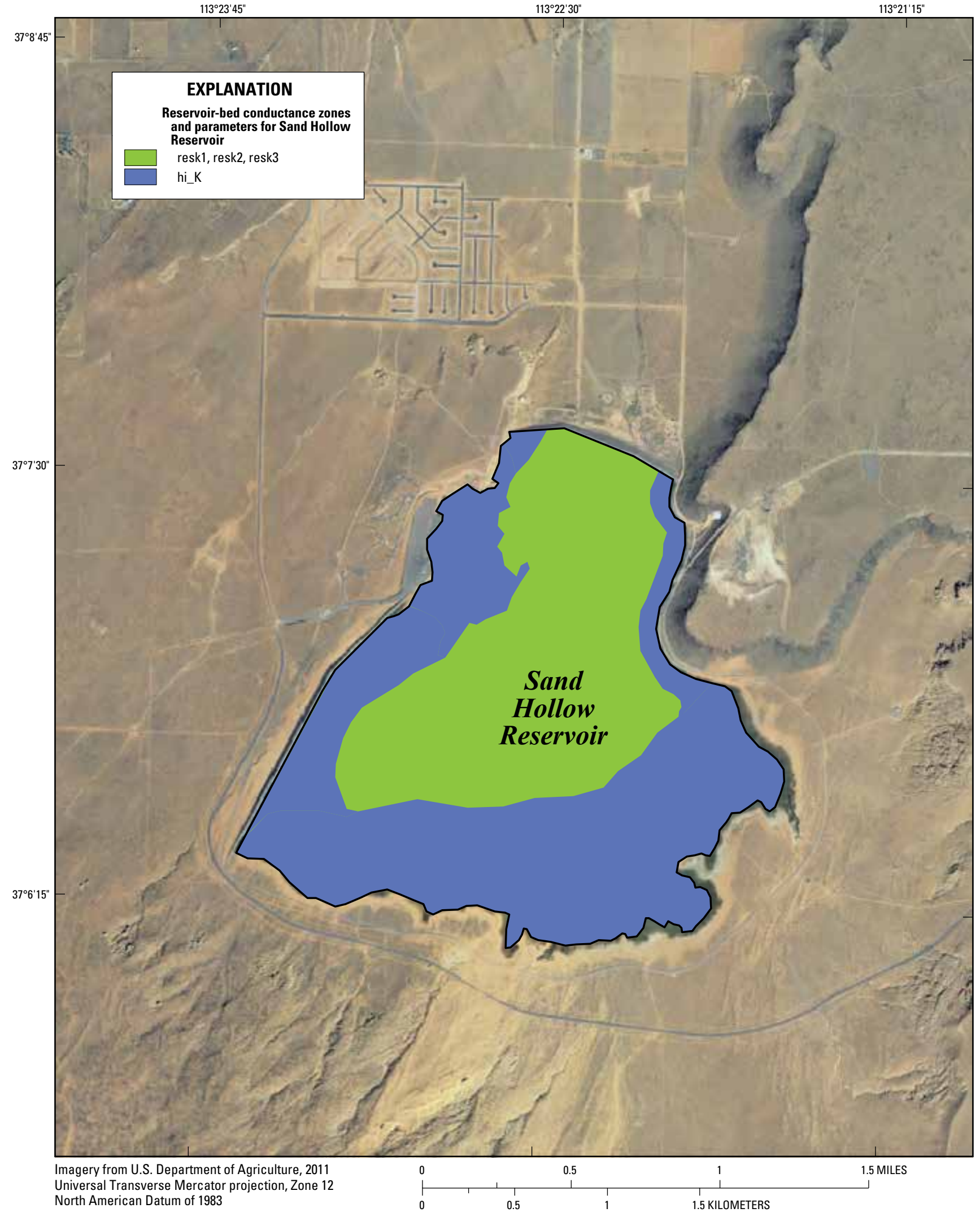

Figure 14. Bed conductance zones of the Reservoir Package representing vertical hydraulic conductivity beneath Sand Hollow Reservoir, Hurricane Bench area, Utah. 


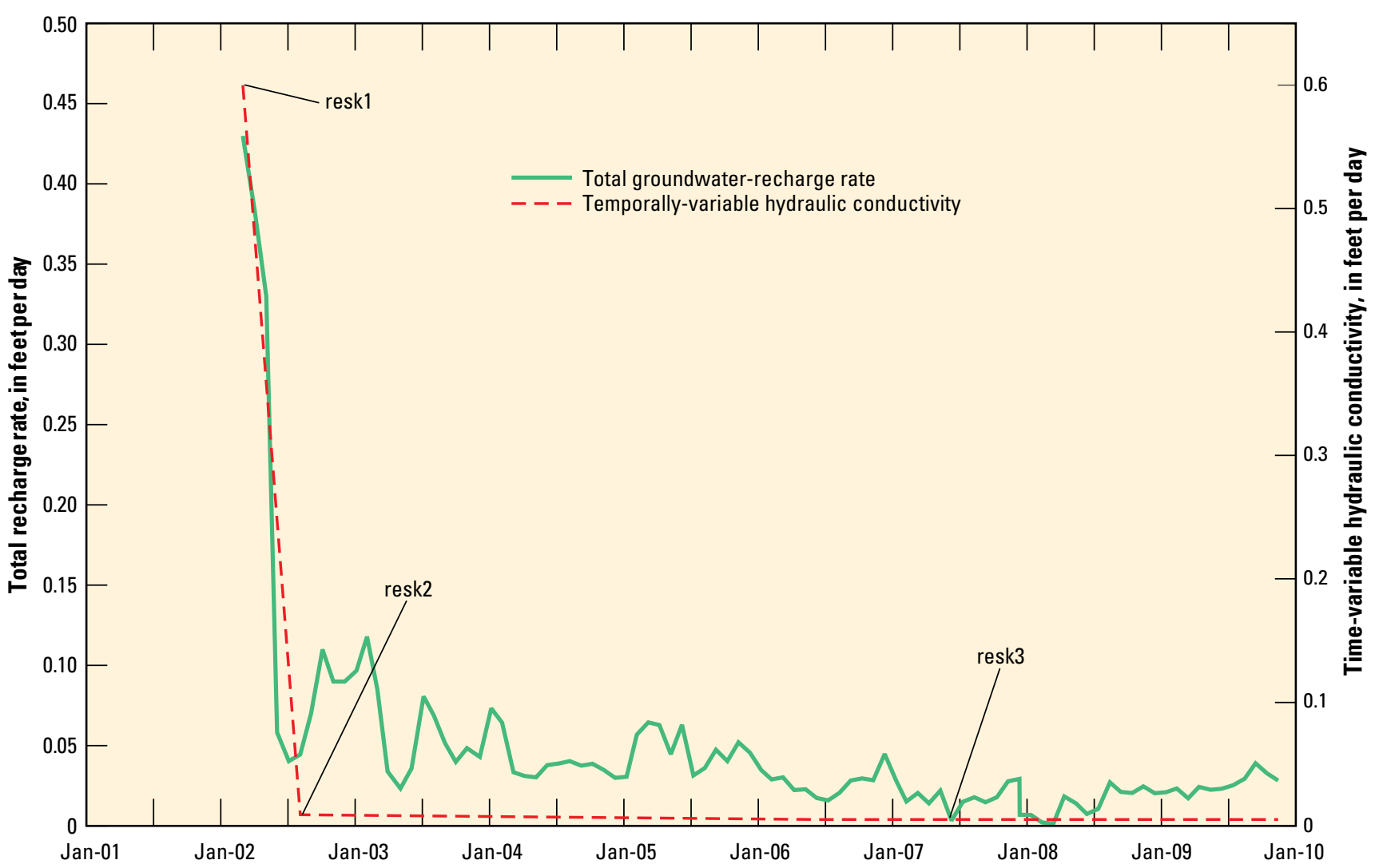

Figure 15. Temporally varying reservoir-bed hydraulic conductivity parameters that define a portion of the total recharge simulated in flat low-lying areas in Sand Hollow Reservoir, Hurricane Bench area, Utah.

conductance multiplier value equal to the horizontal hydraulic conductivity of the Navajo Sandstone in proximity to the drain, which was approximately 0.6 to $0.7 \mathrm{ft} / \mathrm{d}$. Observations were not sensitive to these parameters (fig. 13).

One parameter representing riverbed hydraulic conductivity (rivbed) was assigned a value of $30 \mathrm{ft} / \mathrm{d}$ for all stretches of the Virgin River. Simulated water levels at observation wells were not sensitive to the riverbed parameter, and this large value allowed groundwater to easily leave the system at this boundary.

\section{Model Accuracy}

Because of the large amount of water-level, recharge, and discharge data associated with Sand Hollow Reservoir, the model provided a relatively accurate estimate of hydraulic properties in the vicinity of the reservoir. Because of the paucity of both water-level measurements and aquifer stresses away from the reservoir, hydraulic properties and fluxes simulated by the model in other parts of the Hurricane Bench area had a greater degree of uncertainty, such that other combinations of recharge, discharge, and aquifer properties could yield similar or improved results. Observations provided little information for some model parameters, such as rivbed (fig. 13); as a consequence, it is difficult to assess how well these parameters were estimated in the simulation.

\section{Reservoir Recharge, Drain Discharge, and River Discharge}

The simulated total reservoir recharge between 2002 and 2009 was approximately 94,000 acre-ft, which is within 10 percent of the calculated value of 86,000 acre-ft (fig. 7). Temporal trends closely matched calculated reservoir recharge, except during spring 2002 and spring 2003. These periods corresponded to large pumping events during the early filling of the reservoir, and the mismatches were likely the result of not simulating vadose zone saturation, which is a limitation of the Reservoir Package in MODFLOW.

The simulated total drain discharge from 2003 to 2009 was approximately 9,500 acre-ft — about 30 percent less than the reported amount of 14,200 acre-ft. Simulating drain pumping as head-dependent discharge through a hydraulic conductivity contrast (drain conductance) likely underestimated the discharge because it did not simulate the effects of dewatering the adjacent saturated flow system due to pumping. As a result of the vertical discretization in the model, however, the Well Package could not be used to simulate this drain pumping because wells were simulated as single node discharge points in the center of a cell. The thickness of layer 1 near Sand Hollow was approximately $200 \mathrm{ft}$; thus, the point of stress for a well would have been $80 \mathrm{ft}$ below the base of the drains when using the Well Package. At this greater depth, the stress would have resulted in an inaccurate groundwater-flow gradient 
in proximity to the reservoir, adversely affecting simulated reservoir recharge. Though trends in simulated drain discharge generally approximated those of the reported drain pumping (fig. 9), there were large differences in late 2006 and from mid-2007 through 2009. These periods coincided with operation of the pumps in the West Dam Spring drain, which were turned on intermittently. Differences between simulated and reported drain discharge during 2004 and 2005 were much less because the North Dam Drain was the only drain in operation until July 2005 and was pumped on a more constant basis.

Final model output yielded an approximate gain of 2,160 acre-ft to the Virgin River during 1975 (steady-state conditions) for the model domain, with 1,740 acre-ft in 1995, and 1,880 acre-ft in 2009 . The year 1995 represented the lowest discharge to the Virgin River during the simulation because 1995 corresponded to the greatest stress to the aquifer as a result of well withdrawals from 1975 to 2009. Discharge to the Virgin River had not recovered to pre-reservoir steady state amounts by 2009. The simulated discharge to the Virgin River was within the range of half of the estimated 5,220 acre-ft/ yr discharge to the river for reaches of the river measured by Herbert (1995) within the study area.

\section{Simulated Water Levels}

Simulated water levels were generally within $10 \mathrm{ft}$ of measured water levels at most observation sites (fig. 16) throughout the period of simulation. Larger differences between simulated and observed water levels of up to approximately $15 \mathrm{ft}$ were generally found at observation sites located more than 1 mi north of the reservoir near wells WD RJ and WD 17 through WD 20 (fig. 17). Except for WD RJ, these monitoring wells had a much shorter period of record compared to WD 1-14 that limited a comparison of trends in the simulated and observed hydrographs, which are not presented in this report but are available in Heilweil and Marston (2011). An observation well located even farther north, (C-42-14)12dbb-1, had similar simulated versus observed water-level differences of 0 to $15 \mathrm{ft}$ for the period of record, but the shape of the simulated hydrograph compared to the observed hydrograph showed an adequate match (fig. 16). The overall combined fit of the model to both the water-level and reservoir recharge observations indicated that the simulated hydraulic properties and boundary conditions were well constrained and provided a reasonable representation of the groundwater system. The simulated increase in water levels in the aquifer resulting from reservoir recharge corresponded to a simulated increase in groundwater storage of about 70,000 acre-ft from 2002 to 2009. This value is less than the simulated reservoir recharge of 94,000 acre-ft for the same period. The difference is attributed primarily to discharge from wells and drains.

\section{Environmental Tracers}

To determine if the model adequately simulated groundwater-flow directions and travel times, MODPATH (Pollock, 1994) was used to compare simulated travel times from the reservoir to the monitoring wells to travel times estimated on the basis of the observed arrival of environmental tracers in those monitoring wells. The chemical and isotopic characteristics of reservoir recharge water, including the chloride-to-bromide ratio ( $\mathrm{Cl}: \mathrm{Br})$, major-ion chemistry, chlorofluorocarbons (CFCs), tritium $\left({ }^{3} \mathrm{H}\right)$, and field parameters (total dissolved-gas pressure, dissolved oxygen, and specific conductance), were used to track groundwater movement in the aquifer. The concentration of each of these constituents in reservoir recharge is significantly different than in the native groundwater, making them useful tracers of the movement of reservoir water into the surrounding aquifer. The arrival of recharge from the reservoir has been documented in three monitoring wells (WD 6, WD 9, and WD 11) near the reservoir (Heilweil and Marston, 2011). In general, these tracers indicated that reservoir water arrived at the nearby wells in the following years: arrival at WD 9 between 2003 and 2006, arrival at WD 11 between 2005 and 2006, and arrival at WD 6 between 2005 and 2009.

MODPATH predicted the simulated arrival time for reservoir water at WD 9 between 2003 and 2006, at WD 11 between 2004 and 2008, and no arrival at WD 6 by 2009 (fig. 18). Simulated arrival times for WD 9 and WD 11 matched observed arrival times adequately. In contrast to the environmental tracer data, MODPATH particles did not arrive at WD 6 because of the pumping influence of well 8 , which is located between the reservoir and WD 6. Observed tracer arrivals in WD 6 were likely the result of more rapid groundwater movement in fractures than was simulated by the groundwater model, which assumes flow is through a homogenous, porous media. Although the fractured areas in Hurricane Bench were simulated as zones of greater hydraulic conductivity, they were simulated as porous media rather than fracture flow. Both well 8 and WD 6 lie within a zone of mapped fractures (Heilweil and others, 2000; P.D. Rowley, Geologic Mapping, Inc., unpub. data, 2004). Open fractures observed by Heilweil and Solomon (2004) could allow for greater localized groundwater velocities not explicitly simulated by MODFLOW.

\section{Model Projections}

The groundwater-flow model was used to predict the future movement of reservoir water through the groundwater system toward the Virgin River. The model also was used to estimate the additional groundwater storage if the reservoir continued to operate until a new steady state groundwater system was achieved. The projection assumed the same distribution of groundwater withdrawal from wells as was recorded in September 2009, which was approximately equal to the March 2006 through December 2009 average. During this stress period, most of the pumping took place at well 8 and well 9, with lesser withdrawals at well 2 and well 21. In the future projection, the reservoir stage was specified as constant at the December 2009 value of 3,044 ft, or about $16 \mathrm{ft}$ below full stage. The effects of withdrawals from other wells or different reservoir stage conditions were not projected. The projection (beginning in January 2010) simulated these conditions for 

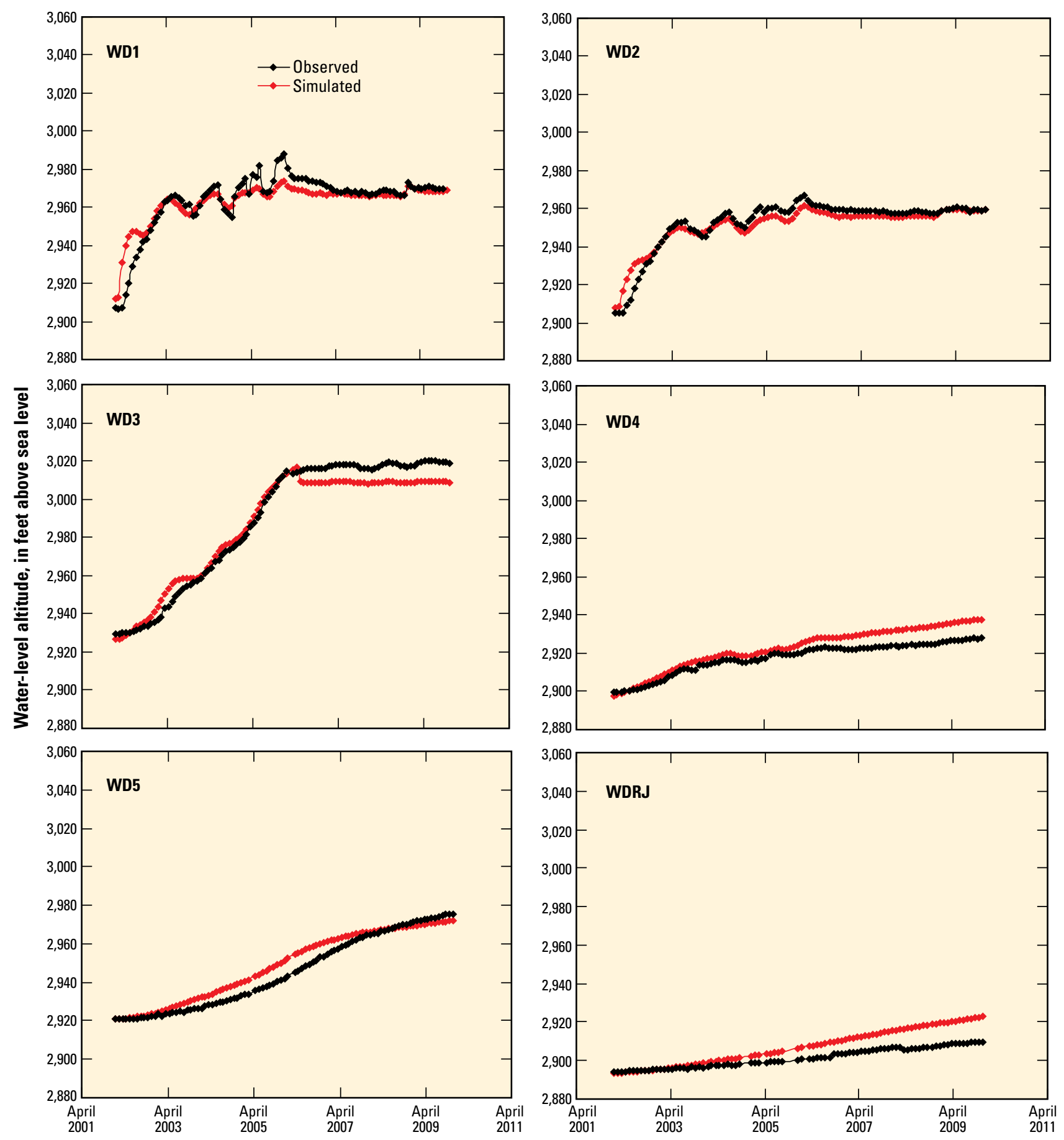

See figure 3 for location of monitoring wells

Figure 16. Observed and simulated water levels at monitoring wells in Sand Hollow, Hurricane Bench area, Utah. 


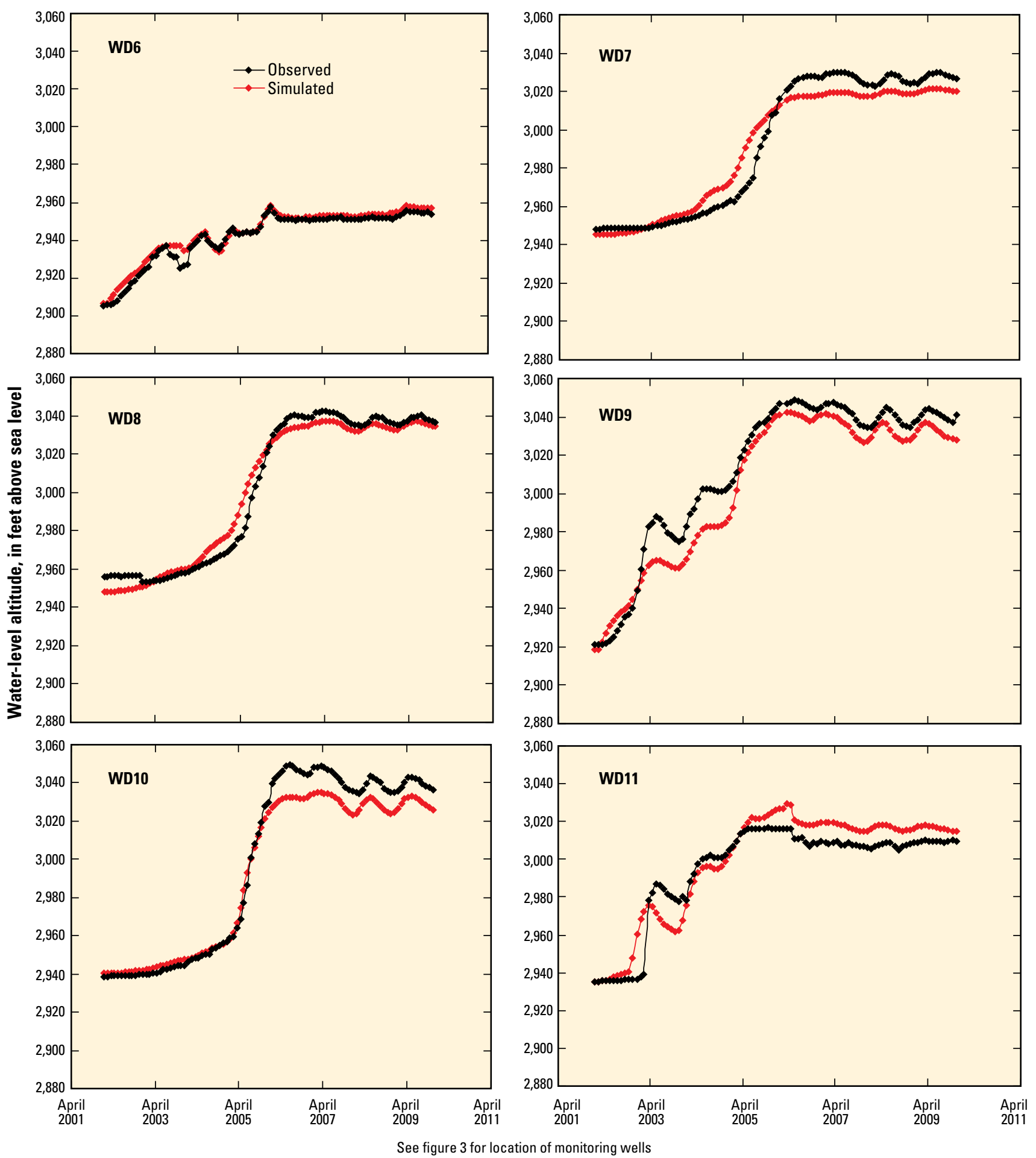

Figure 16. Observed and simulated water levels at monitoring wells in Sand Hollow, Hurricane Bench area, Utah.—Continued 

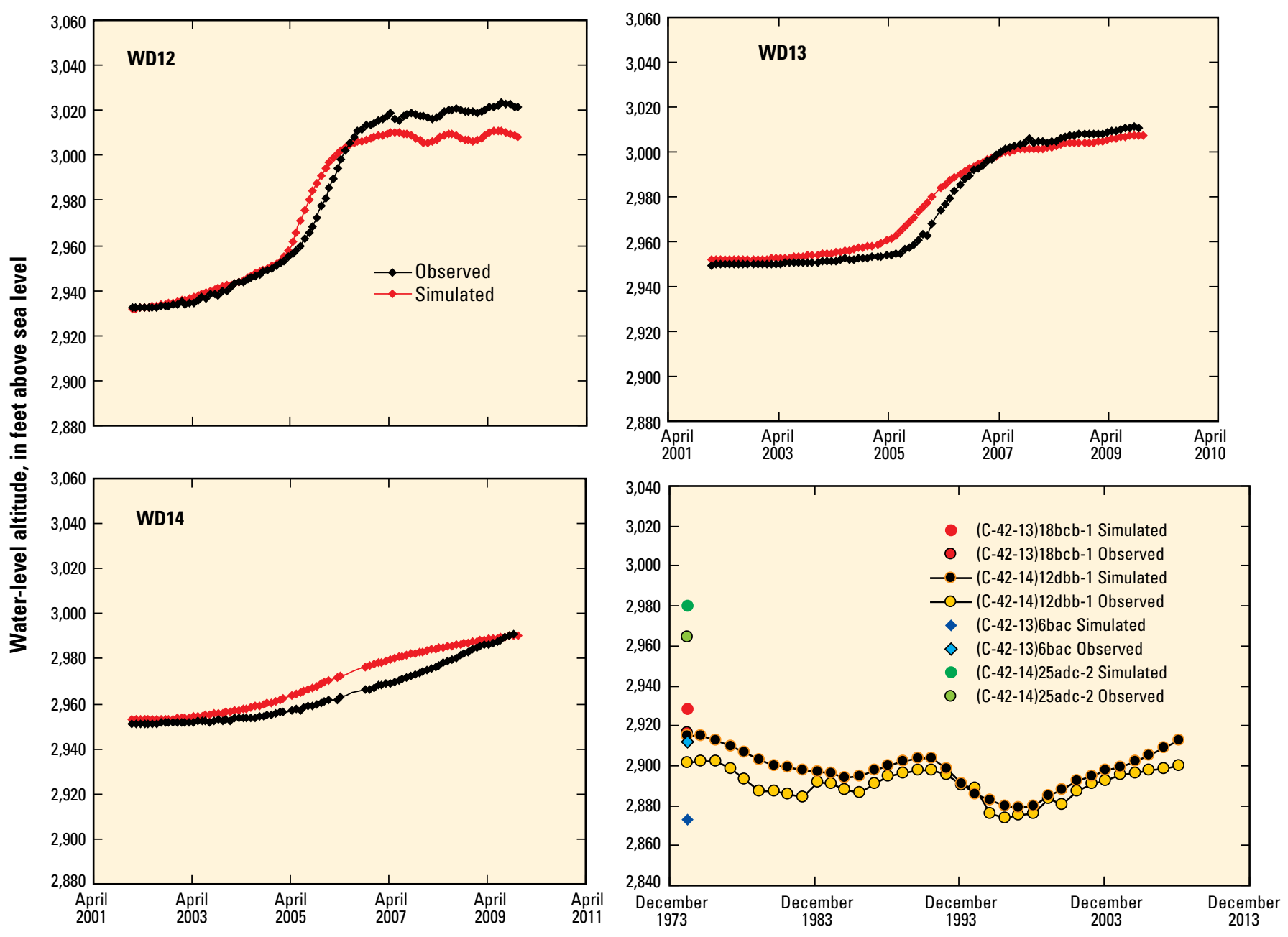

See figure 3 for location of monitoring wells

Figure 16. Observed and simulated water levels at monitoring wells in Sand Hollow, Hurricane Bench area, Utah. - Continued

one 1,000-year stress period by using ten 100 -year time steps. To estimate the travel time of reservoir water to the Virgin River, MODPATH (Pollock, 1994) was used to track particles with starting locations at the top of layer 1 underneath Sand Hollow Reservoir. The effective porosity was assumed to equal the calibrated specific yield of 0.12 . The earliest arrival times at the Virgin River were after approximately 500 years, with an average arrival time for most particles of 800 years (fig. 19). Some of the particles that had starting locations beneath the central portions of the reservoir had longer travel times and flow paths that extended into the deeper parts of the Navajo Sandstone and the Kayenta Formation. Approximately 50 percent of the particles had arrival times in excess of 1,000 years. Steady-state conditions, where simulated groundwater recharge and discharge are approximately equal and there is no change in storage, were attained approximately 300 years after December 2009. The predicted additional groundwaterstorage capacity associated with reservoir recharge in the Hurricane Bench area after December 2009 was approximately 325,000 acre-ft.

\section{Model Limitations}

The numerical model is a simplified representation of the groundwater system and includes limitations regarding the simulation of natural recharge, uncertainty in hydraulic conductivity in areas far from the reservoir, assumptions regarding discharge to the Virgin River, the use of an equivalent porous media model to simulate preferential flow in a fractured dual-permeability aquifer system, the assumption of uniform storage properties, not including the possibility of upwelling higher-salinity groundwater as a form of recharge, and the simulation of withdrawals from shallow drains using the headdependent Drain package.

In this model, natural recharge as infiltration of precipitation was set to values obtained from Heilweil and McKinney (2007) rather than adjusting it during parameter estimation. Also, average long-term recharge rates were assigned rather than accounting for seasonal and annual variability. 


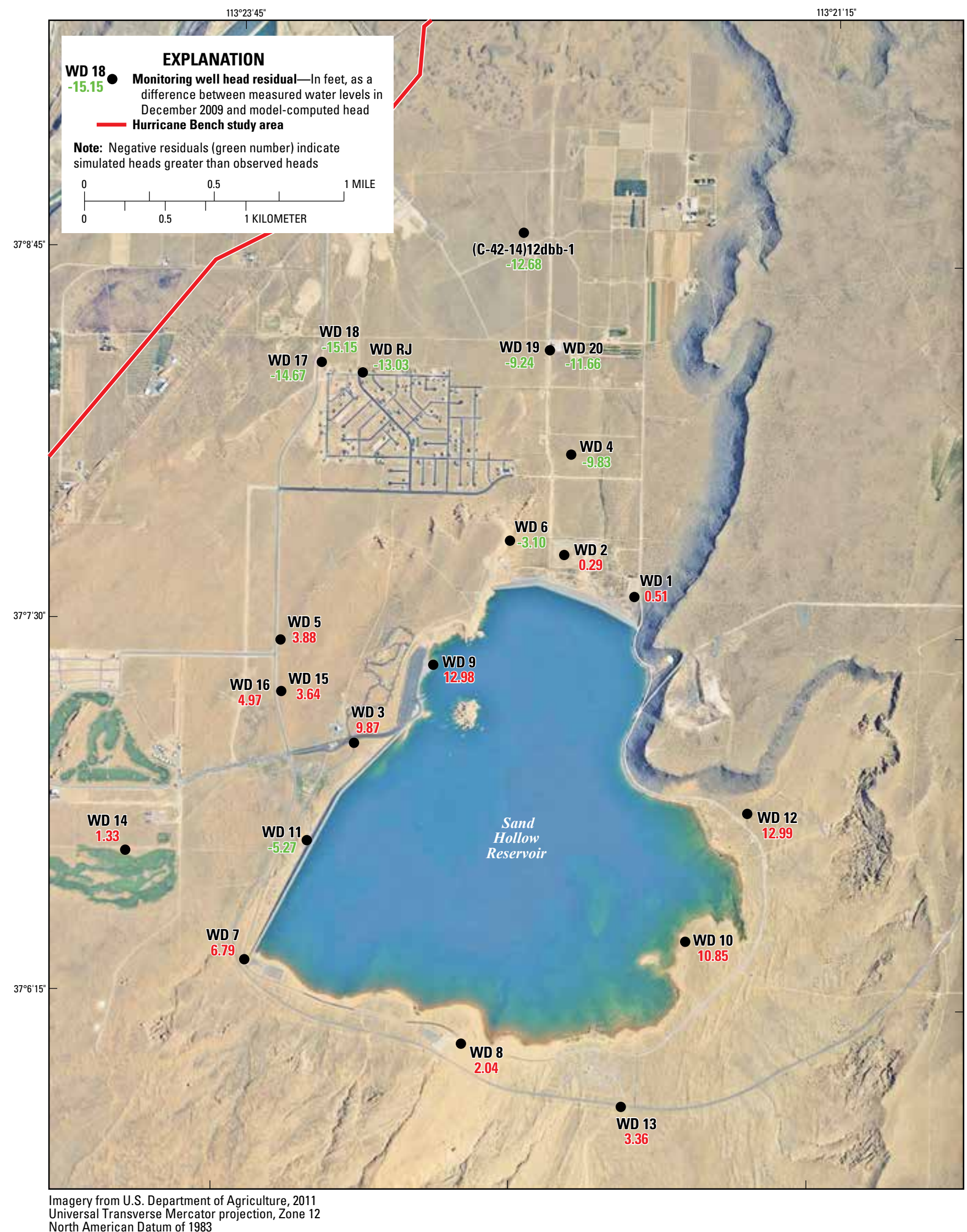

Figure 17. Difference between observed and simulated water levels measured in December 2009 for monitoring wells around Sand Hollow Reservoir, Hurricane Bench area, Utah. 


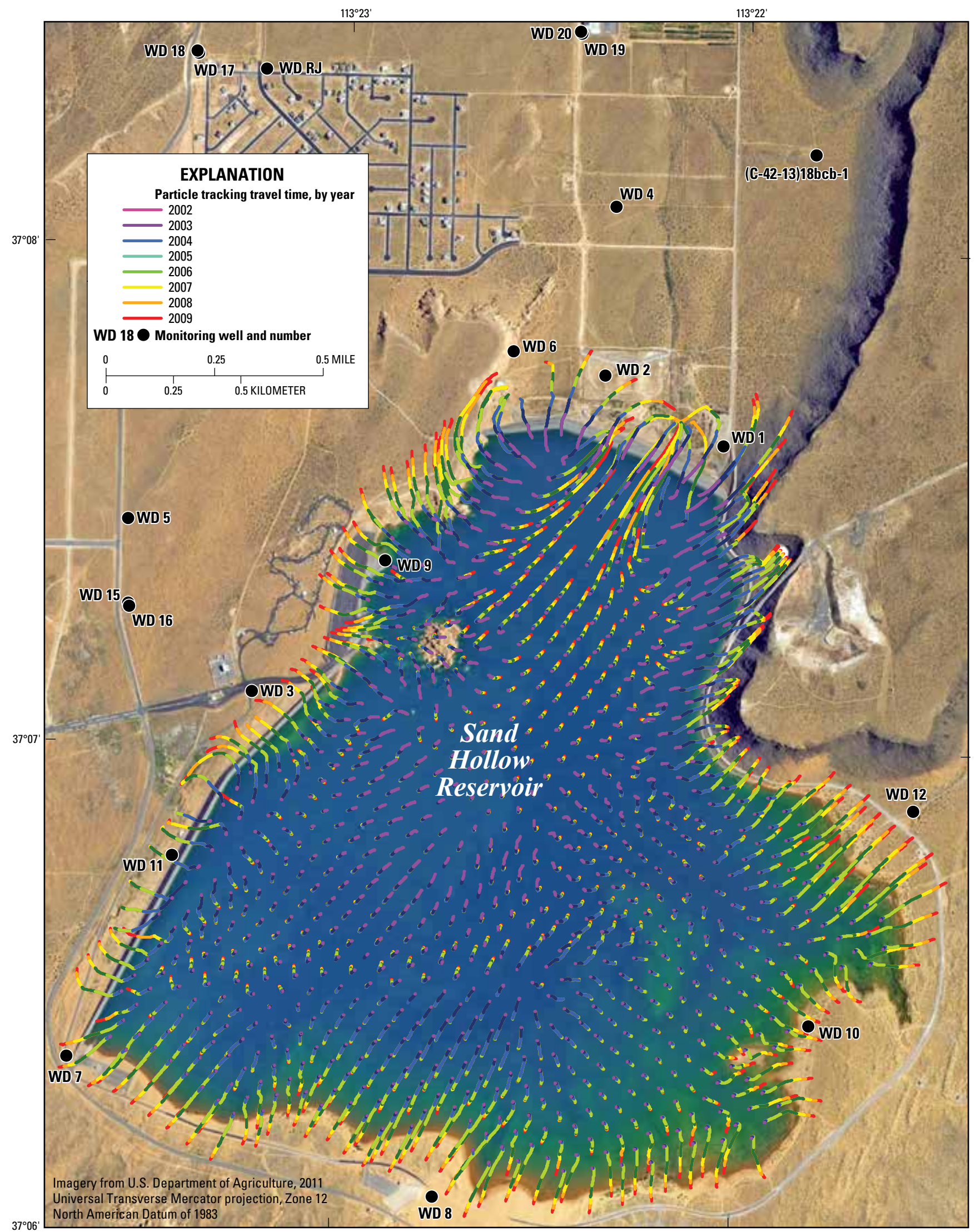

Figure 18. Simulated groundwater-flow paths from Sand Hollow Reservoir, Hurricane Bench area, Utah. 


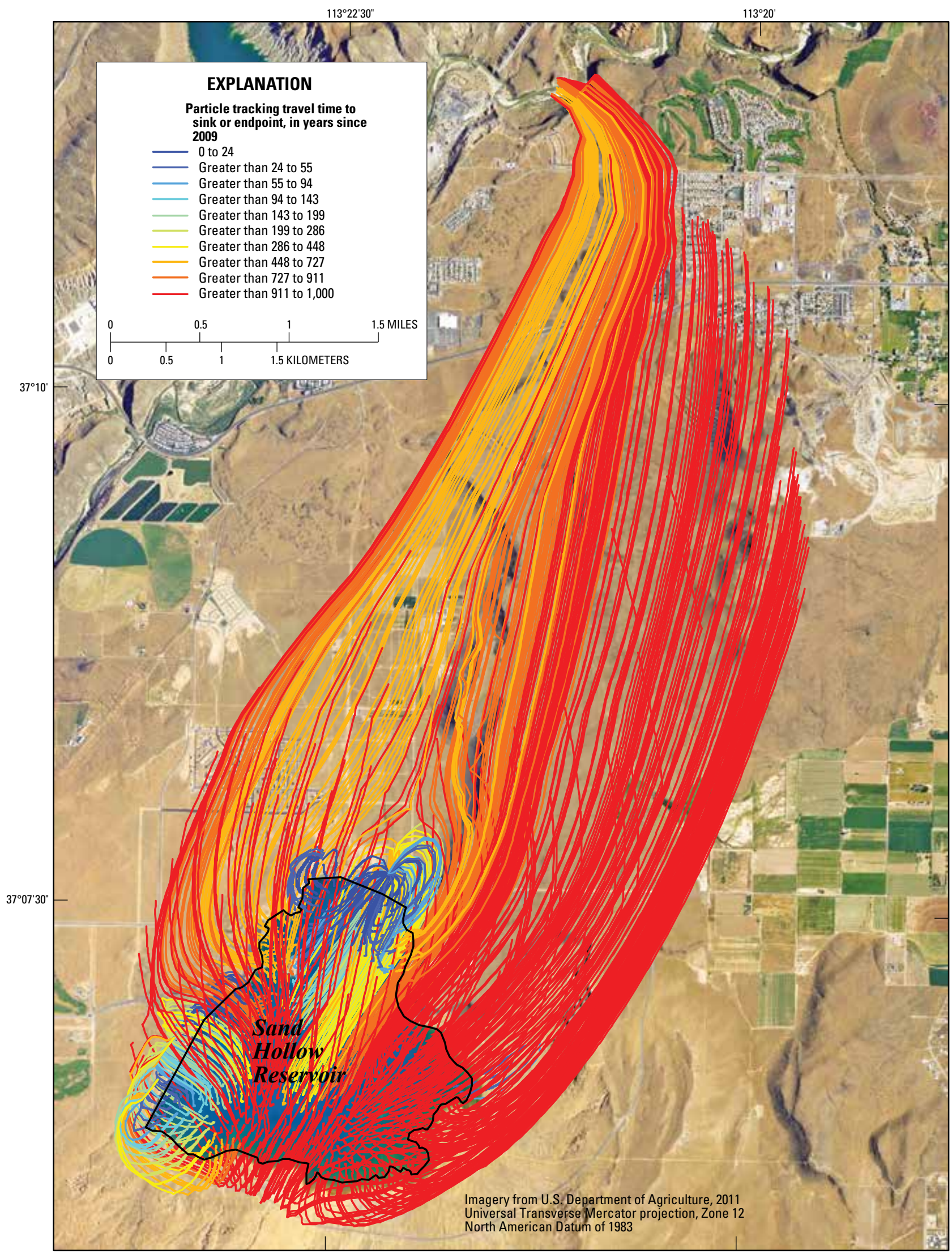

Figure 19. Projected travel time of managed aquifer recharge moving through the Navajo Sandstone in Sand Hollow, Hurricane Bench area, Utah. 
The model simulated a greater rise in water levels farther from the reservoir, such as in the area of well WD RJ, than was observed. Hydraulic-conductivity values assigned to this part of the model could have been too low. The calibrated permeability closer to the reservoir was a better approximation where the aquifer had undergone more stress and more observations for calibration were available.

Another source of uncertainty in the model is the representation of groundwater discharge to the Virgin River. Discharge was simulated to the river from the Navajo Sandstone south of the river. Measured groundwater discharge to the river included flow from north of the river, which was not simulated in the model. The amount of this groundwater discharge, from the southern part of the Navajo Sandstone cannot be quantified but only estimated as less than the $7.2 \mathrm{ft}^{3} / \mathrm{s}$ measured in 1995 . Water-level data near the river and in the northeast portions of the model grid would improve the simulation of groundwater to surface-water interaction along the entire reach of the Virgin River within the model domain.

The aquifer was assumed to be a homogenous porous media, and the model did not explicitly simulate flow through specific fractures. The current model only approximated fracture flow through bulk anisotropy. This could explain the later-than-observed arrival times of environmental tracers at well WD 6. Simulating flow along individual fracture zones was not within the scope of this study.

One value for specific yield was used for the entire simulated Navajo Sandstone. Estimates of additional groundwater storage capacity based on future model predictions assumed a constant value for specific yield. Spatial and temporal variability in specific yield could increase or decrease this value, but no data were available to evaluate spatial variability.

A study by Heilweil and others (2000) indicated that upwelling groundwater from underlying formations contributes up to 1,100 acre-ft/yr to the Navajo Sandstone and Kayenta Formation for a 6- $\mathrm{mi}^{2}$ area located west of Hurricane. This estimate was based only on a solute mass-balance calculation, rather than direct measurement of this potential source of recharge. Also, this upwelling of higher salinity groundwater is located in the vicinity where large withdrawals were made in the 1990s and could have been a short-term transient response to pumping. Because of its relatively small amount and the uncertainty associated with its long-term occurrence, it was not considered in this study's groundwater budget. Further investigation of this form of recharge would be necessary before inclusion in this groundwater-flow model.

Another limitation of the model is the simulation of withdrawals from shallow drains by using the Drain Package. Use of the Well Package to simulate this discharge would have required much finer vertical discretization of the shallow part of the aquifer system than was practical for this regional groundwater-flow model.

\section{Summary}

The purpose of this report was to present the construction, calibration, and projected results of a numerical simulation of groundwater movement in the Hurricane Bench area, including managed aquifer recharge from Sand Hollow Reservoir. This study incorporated data presented in previous reports that documented pre-reservoir vadose-zone and groundwater conditions in Sand Hollow and the Hurricane Bench area prior to March 2002; pond and trench infiltration studies adjacent to the reservoir; and post-reservoir groundwater conditions, water budgets, and estimates of groundwater recharge from the reservoir from March 2002 through December 2009.

Natural recharge as infiltration of precipitation was approximately 2,100 acre-ft/yr from 2002 to 2009 (totalling about 16,800 acre-ft). Discharge included seepage to the Virgin River, municipal- and irrigation-well withdrawals, and drains at the base of reservoir dams. Seepage from the Hurricane Bench to the Virgin River was estimated to be about 2,100 acre-ft/yr under natural conditions. Total well withdrawals from 1975 to 2009 ranged from 130 to about 3,000 acre-ft/yr. Managed aquifer recharge from Sand Hollow Reservoir to the underlying Navajo aquifer was calculated to be about 86,000 acre-ft from 2002 to 2009 . Groundwater levels in monitoring wells closest to the reservoir generally rose between 2002 and 2006 and then fluctuated with reservoir altitude and nearby pumping from production wells. Water levels in monitoring wells farther from the reservoir were still rising through 2009.

The objective of the numerical groundwater-flow model was to obtain a simulation that reasonably represented groundwater recharge, movement, discharge, and measured water levels in the Hurricane Bench area. The simulated recharge from Sand Hollow Reservoir between 2002 and 2009 was approximately 94,000 acre-ft, which was within 10 percent of the calculated value. The simulated total drain discharge from 2003 to 2009 was approximately 9,500 acre-ft. This value was 4,700 acre-ft less than reported drain pumpage because passive drains were simulated by using a seepage face that did not simulate the spatially larger effects of dewatering due to pumping. A head-dependent groundwater discharge of about 1,740 acre-ft to the Virgin River was simulated during 1995, increasing to about 1,880 acre-ft in 2009. Simulated arrival times of environmental tracers at monitoring wells WD 9 and WD 11 were within the ranges of observed arrival times from 2003 to 2008 . In general, the groundwater-flow model adequately simulated water levels, and most simulated water levels were within $10 \mathrm{ft}$ of the measured water levels. The overall fit of the model to water levels, estimated reservoir recharge, and measured discharge indicated that the simulated hydraulic properties and boundary conditions provided a reasonable representation of the groundwater-flow system.

The simulated change in water levels caused by managed aquifer recharge at Sand Hollow Reservoir corresponded to an increase in groundwater storage of about 70,000 acre-ft between 2002 and 2009. The model predicted an estimated 
325,000 acre-ft of total additional groundwater storage for the Hurricane Bench area when steady state is eventually reached (approximately 300 years from 2009), assuming constant reservoir operating conditions and well withdrawals, as observed in late 2009. The simulated earliest arrival time of reservoir water to the Virgin River was 500 years from 2009, with an average arrival time of 800 years from 2009.

\section{References Cited}

Burden, C.B., and others, 2010, Groundwater conditions in Utah, spring of 2010: State of Utah Department of Natural Resources Cooperative Investigations Report No. 51, 135 p.

Cordova, R.M., 1978, Ground-water conditions in the Navajo Sandstone in the central Virgin River basin, Utah: State of Utah Department of Natural Resources Technical Publication No. 61, 66 p.

Cordova, R.M., Sandberg, G.W., and McConkie, W., 1972, Ground-water conditions in the central Virgin River basin, Utah: Utah Department of Natural Resources Technical Publication No. 40, 64 p.

Fenske, J.P., Leake, S.A., and Prudic, D.A., 1996, Documentation of a computer program (RES1) to simulate leakage from reservoirs using the modular finite-difference groundwater flow model (MODFLOW): U.S. Geological Survey Open-File Report 96-364, 51 p.

Harbaugh, A.W., 2005, MODFLOW-2005, The U.S. Geological Survey modular ground-water model-the ground-water flow process: U.S. Geological Survey Techniques and Methods 6-A16, variously paged.

Heilweil, V.M., Freethey, G.W., Stolp, B.J., Wilkowske, C.D., and Wilberg, D.E., 2000, Geohydrology and numerical simulation of ground-water flow in the central Virgin River basin of Iron and Washington Counties, Utah: Utah Department of Natural Resources Technical Publication 116, $182 \mathrm{p}$.

Heilweil, V.M., and Marston T.M., 2011, Assessment of managed aquifer recharge from Sand Hollow Reservoir, Washington County, Utah, updated to conditions in 2010: U.S. Geological Survey Scientific Investigations Report 2011-5142, $39 \mathrm{p}$.

Heilweil, V.M., and McKinney T.S., 2007, Net-infiltration map of the Navajo Sandstone outcrop area in western Washington, County, Utah: U.S. Geological Survey Scientific Investigations Map 2988.

Heilweil, V.M., McKinney T.S., Zhdanov, M.S., and Watt, D.E., 2007, Controls on the variability of net infiltration to desert sandstone: Water Resources Research, v. 43 (W07431) DOI: 10.1029/2006WRR005113, 15 p.
Heilweil, V.M., Ortiz, G., and Susong, D.D., 2009a, Assessment of managed aquifer recharge at Sand Hollow Reservoir, Washington County, Utah, updated to conditions through 2007: U.S. Geological Survey Scientific Investigations Report 2009-5050, 20 p.

Heilweil, V.M., and Solomon, D.K., 2004, Millimeter- to kilometer-scale variations in vadose-zone bedrock solutes: implications for estimating recharge in arid settings, in Phillips, F., Scanlon, B., and Hogan, J., eds., Ground-water recharge in a desert environment: the southwestern United States: Water Science and Application, v. 9, American Geophysical Union, Washington, D.C., p. 49-67.

Heilweil, V.M., Solomon, D.K., and Gardner, P.M., 2006, Borehole environmental tracers for evaluating net infiltration and recharge through desert bedrock: Vadose Zone Journal, v. 5, p. 98-120.

Heilweil, V.M., Solomon, D.K., and Ortiz, G., 2009b, Silt and gas accumulation beneath an artificial recharge spreading basin, southwestern Utah, U.S.A.: Boletín Geológico y Minero, v. 120, no. 2, p. 185-195.

Heilweil, V.M., Solomon, D.K., Perkins, K.S., and Ellett, K.M., 2004, Gas-partitioning tracer test to quantify trapped gas during recharge: Ground Water, v. 42 , no. 4, p. 589-600.

Heilweil, V.M., and Susong, D.D., 2007, Assessment of artificial recharge at Sand Hollow Reservoir, Washington County, Utah, updated to conditions through 2006: U.S. Geological Survey Scientific Investigations Report 2007-5023, 14 p.

Heilweil, V.M., Susong, D.D., Gardner, P.M., and Watt, D.E, 2005, Pre- and post-reservoir ground-water conditions and assessment of artificial recharge at Sand Hollow, Washington County, Utah, 1995-2005: U.S. Geological Survey Scientific Investigations Report 2005-5185, 74 p.

Heilweil, V.M., and Watt, D.E., 2011, Trench infiltration for managed aquifer recharge to permeable bedrock: Hydrological Processes, v. 25, p. 141-151.

Herbert, L.R., 1995, Seepage study of the Virgin River from Ash Creek to Harrisburg Dome, Washington County, Utah: Utah Department of Natural Resources Technical Publication No. 106,8 p.

Hill, M.C., Banta, E.R., Harbaugh, A.W., and Anderman, E.R., 2000, MODFLOW-2000, the U.S. Geological Survey modular ground-water flow model, User's guide to the observation, sensitivity, and parameter-estimation process and three-post processing programs: U.S. Geological Survey Open-File Report 00-184, 209 p. 
Hill, M.C., and Tiedeman, C.R., 2007, Effective groundwater calibration: with analysis of data, sensitivities, predictions, and uncertainty: Wiley and Sons, Hoboken, New Jersey, $464 \mathrm{p}$.

Hurlow, H.A., 1998, The geology of the central Virgin River basin, southwestern Utah, and its relation to ground-water conditions: Utah Department of Natural Resources Water Resources Bulletin 26, 53 p.

Jensen, M.E., Lowe, M., and Wireman, M., 1997, Investigation of hydrogeologic mapping to delineate protection zones around springs: Report of two case studies: U.S. Environmental Protection Agency Report 600/R-97/023, 60 p.

Poeter, E.P., Hill, M.C., Banta, E.R., Mehl, S., and Christensen, S., 2005, UCODE_2005 and six other computer codes for universal sensitivity analysis, calibration, and uncertainty evaluation: U.S. Geological Survey Techniques and Methods 6-A11, $283 \mathrm{p}$.

Pollock, D.W., 1994, User's guide to MODPATH/MODPATHPLOT, Version 3: a particle tracking post-processing package for MODFLOW, the U.S. Geological Survey finite-difference ground-water flow model: U.S. Geological Survey Open-File Report 88-729, 113 p.

RB\&G Engineering, Inc., 1994, Sand Hollow groundwater recharge and storage project, Washington County, Utah: Feasibility study, April 1994, 11 p., 2 appendices.

Weigel, J.F., 1987, Selected hydrologic and physical properties of Mesozoic formations in the upper Colorado River Basin in Arizona, Colorado, Utah, and Wyoming - excluding the San Juan Basin: U.S. Geological Survey Water-Resources Investigations Report 86-4170, 68 p.

Wilkowske, C.D., Heilweil, V.M., and Wilberg, D.E., 1998, Selected hydrologic data for the central Virgin River Basin area, Washington and Iron Counties, Utah, 1915-97: U.S. Geological Survey Open-File Report 98-389, 53 p. 



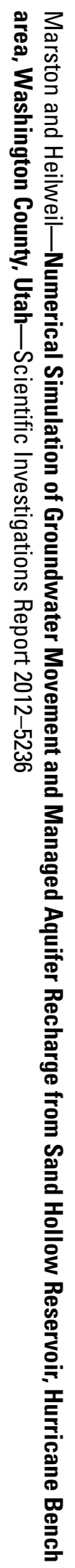

9 Printed on recycled paper 